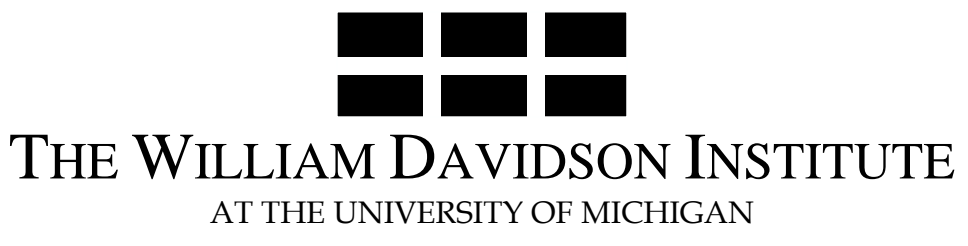

AT THE UNIVERSITY OF MICHIGAN

\title{
Foreign News and Spillovers in Emerging European Stock Markets
}

\author{
By: Evzen Kocenda and Jan Hanousek
}

William Davidson Institute Working Paper Number 983

May 2010 


\title{
Foreign News and Spillovers in Emerging European Stock Markets
}

\author{
Jan Hanousek* \\ and \\ Evžen Kočenda**
}

\begin{abstract}
We analyze foreign news and spillovers in the emerging EU stock markets (the Czech Republic, Hungary, and Poland). We employ high-frequency five-minute intraday data on stock market index returns and four classes of EU and U.S. macroeconomic announcements during 2004-2007. We account for the difference of each announcement from its market expectation and we jointly model the volatility of the returns accounting for intraday movements and day-of-the-week effects. Our findings show that intraday interactions on the new EU markets are strongly determined by mature stock markets as well as the macroeconomic news originating thereby. We show that strong contemporaneous links across markets are present even after controlling for macroeconomic announcements. Finally, in terms of specific announcements, we are able to show the exact sources of macro news spillovers from the developed foreign markets to the three new EU markets under research.
\end{abstract}

Keywords: finance, intra-day data, macroeconomic news, European emerging stock markets, volatility

JEL Classification: C52, F36, G15, P59

* CERGE-EI, Charles University and the Academy of Sciences, Prague, Czech Republic; Anglo-American University, Prague; The William Davidson Institute, Michigan; and CEPR, London. -mail: jan.hanousek@cergeei.cz.

** CERGE-EI, Charles University and the Academy of Sciences, Prague, Czech Republic; Anglo-American University, Prague; CESifo, Munich; The William Davidson Institute, Michigan; CEPR, London; Osteuropa Institut, Regensburg. E-mail: evzen.kocenda@cerge-ei.cz.

We would like to thank John Banko, John Brinkman, T.A. Chola, Dana Hájková, Iuliana Ismailescu, Petr Koblic, Evan Kraft, and Magdalena Malinowska. We also acknowledge helpful comments from participants at the following conferences; FMA (Prague, 2008; Torino, 2009), Monetary and Financial Transformations in the CEECs (Paris, 2008), the XVII International Tor Vergata Conference on Banking and Finance (Rome, 2008), BESI (Acapulco, 2009), CICM (London, 2009), and CESifo (Munich, 2010). GAČR grant (402/08/1376) support is gratefully acknowledged. The usual disclaimer applies. 


\section{Introduction, Motivation and Related Literature}

Financial globalization has fostered stronger links among developed markets and brought emerging markets under their increasing influence. Spillovers and macroeconomic news from developed markets are two prominent types of impact emerging markets receive. This impact is important due to its potential to affect equity price formation based on news about macroeconomic fundamentals. The effect of macroeconomic news and spillovers is quite well documented in developed markets across the classes of assets (Andersen et al., 2007) and the transmission of macroeconomic announcements across emerging equity markets is closely examined in Wongswan (2006). However, the effect of news and spillovers in emerging European equity markets is grossly under-researched.

In this paper we analyze the effect of foreign news and spillovers in three emerging European stock markets that have, relatively recently, begun their integration with mature European Union (EU) markets. We focus on emerging EU stock markets the Czech Republic, Hungary and Poland for several reasons. They are relevant and interesting to analyze since these markets are the most liquid as well as the largest in terms of market capitalization in the region (Égert and Kočenda, 2007). Further, strong trade links with the EU, the heavy presence of foreign institutional investors from developed markets, and the large volumes foreigner investors trade on the three stock markets set the stage for announcements from developed markets to directly impact these emerging markets. Our results provide evidence that spillovers as well as macroeconomic announcements from developed markets (in the EU and the U.S.A.) do impact the three markets under research in a way that is consistent with findings in other regions in Asia and Latin America.

A large number of studies approach the issue of price formation on the emerging markets with the help of causality techniques to show that price movements on developed markets influence their emerging counterparts. This paper is differentiated from this array of literature in that we show how information in terms of macroeconomic news and expectations on developed markets is able to affect price formation on emerging markets. This we show even when accounting for price developments on developed markets.

Our approach is to use unique intra-day frequency stock price data in order to capture information flowing from developed markets in almost continuous time and to illustrate its power on price formation in emerging markets. We also use a large set of macroeconomic news that is synchronized with the expectations of market participants. This arrangement allows us to identify and analyze unexpected or surprising components of the news. Hence, 
we are able to show the exact sources of macro news spillovers from the developed foreign markets to the three new EU markets under research.

Modern research draws attention to the use of intraday data that are able to reveal the effect of macroeconomic announcements on stock market movements (Bollerslev and Cai, 2000; Nikkinen et al., 2006; Jones, Lin and Masih, 2005; Erenburg, Kurov and Lasser, 2005; Rigobon and Sack, 2006). In our paper we contribute to the related literature in several ways. Most of the literature targets the developed capital markets in the U.S. and Europe, while we focus on European emerging markets. Further, as an extension to the above literature, we use stock price data based on five-minute intervals to provide more robust estimates of public information on stock returns in the new EU markets. To date, this is not covered in the literature on the region. ${ }^{1}$

Further, the majority of studies focus only on a few macroeconomic announcements. In particular, most of them analyze only one event, namely the impact of monetary policy news on stock returns. ${ }^{2}$ However, if there are other major announcements in the same time frame, then focusing only on monetary policy or only a few announcements may bias the estimated coefficients and hence may explain the poor performance of macroeconomic announcements in explaining asset returns. ${ }^{3}$ Hence we use a larger set of macroeconomic releases than employed in previous studies; the announcements and their grouping are specified in the data section. In this respect we concentrate on foreign announcements as the countries under research are small and highly open economies. As such they exhibit significant trade and financial linkages as well as institutional arrangements with respect to the EU. ${ }^{4}$

Finally, previous studies tend to investigate the impact of macro news only on conditional returns, assuming that stock returns do not exhibit time-varying volatility. ${ }^{5}$ In this

\footnotetext{
${ }^{1}$ Exceptions are Hanousek, Kočenda and Kutan (2009), who study the effect of multiple versus single news on intraday frequency, and Černý and Koblas (2005) who analyze the speed of information transmission. Other literature deals with emerging markets in Europe but on a lower frequency and without the specific effect of macroeconomic announcements (see e.g. Tse, Wu and Young, 2003; Smith and Ryoo, 2003; Korczak and Bohl, 2005; and Serwa and Bohl, 2005; among others).

${ }^{2}$ The recent studies include Bomfim (2001), Ehrmann and Fratzscher (2004, 2006), Rigobon and Sack (2006), Bredin, Hyde, and O'Reilly (2005), He (2006), Wongswan (2006), and Morgese-Borys and Zemčík (2009).

${ }^{3}$ To our knowledge, exceptions are Flannery and Protopapadakis (2002) and Andersen et al. (2007) who employed 17 and 25 U.S. macroeconomic news announcements, respectively.

${ }^{4}$ These studies include Jensen, Mercer, and Johnson (1996), Patelis (1997), Siklos and Anusiewicz (1998), Flannery and Protopapadakis (2002), Gurkaynak et al. (2004), Nikkinen and Sahlström (2004), Bredin et al. (2005), Albuquerque and Vega (2006), He (2006) and Ramchander et. al (2006).

${ }^{5}$ Studies that also analyze volatility are for example Bomfim (2001), Poshakwale and Murinde (2001), Murinde and Poshakwale (2001), Kasch-Haroutounian and Price (2001), Bohl and Henke (2003), Kim et al. (2004), and Jones et al. (2005), who utilize time-varying (GARCH) models.
} 
study, we model both conditional returns and the conditional variance of returns simultaneously in a time-varying $(\mathrm{GARCH})$ framework to better capture the impact of macroeconomic announcements of stock returns and to assess intra-day and daily effects in stock market volatility at three new EU markets.

The rest of the paper is organized as follows. In Section 2 we introduce our modeling approach, data and definitions. Detailed empirical findings are presented in Section 3. A concluding summary follows.

\section{Data and Methodology}

We analyze the price discovery on the new EU stock markets and concentrate on the stock exchanges in Budapest, Prague, and Warsaw in particular. The evolution of these markets was dependent on the macroeconomic transformation of these countries (Rockinger and Urga, 2000). By now, these markets are the largest European emerging markets in terms of market capitalization as well as the extent of liquidity (Égert and Kočenda, 2007).

We analyze the impact of macroeconomic announcements by employing an augmented version of the generalized autoregressive conditional heteroskedasticity (GARCH) model attributed to Bollerslev (1986). This approach allows us to assess the impact of news on stock returns and assess market volatility, as well as to account for the fact that errors from the mean equation are heteroskedastic. We deviate from the standard sequencing and introduce our data prior to describing the model since a description of the news announcements is needed to better describe our model.

\subsection{Data Set: Stocks and News}

We constructed our dataset from intraday data on three emerging EU markets recorded by Bloomberg. Stock exchange index quotes $\left(I_{i, t}\right)$ for market $i$ are available in five-minute intervals at time $t$ for the stock markets in Budapest (BUX), Prague (PX-50), and Warsaw (WIG-20). In addition to these markets we also employ data from the Frankfurt stock exchange (the German DAX index is used to proxy stock market returns in the Eurozone) and the U.S. Dow Jones Industrial Average of 30 stocks index. Based on these quotes we construct a five-minute stock market index return $R_{i, t}\left(R_{i, t}=\ln \left(I_{i, t} / I_{i, t-1}\right)\right)$ for each market $i$ from time $t-1$ to time $t$. We do not have any missing observations. The time period of our data starts on 1 June 2004 at 9:00 and ends on 30 December 2007 at 16:30 Central European Daylight Time (CEDT). The beginning of our sample intentionally starts after the entry of the 
four countries to the European Union in May 2004. After accounting for weekends and public holidays, the time span gives the following numbers of trading days for each of the three new EU markets: 878 (Budapest), 880 (Prague), and 879 (Warsaw). Descriptive statistics of the stock index returns are presented in Table 1.

The composition of the three indices as of the end of 2007 is as follows. The Budapest index BUX consists of 16 constituents, with four forming the bulk of the index $(91.5 \%)$. The Prague index (PX-50) consists of 13 constituents of which four represent $82.7 \%$ of the index value. The Warsaw index WIG-20 contains 20 constituents and five of them form a majority $(64.0 \%)$. None of the companies that are included in the three indices are exposed to foreign economic conditions in a different way in terms of reporting activities as they are all obliged to report under international accounting standards. The energy, banking and telecom industries dominate all three indices and specifically the banking industry is represented in similar proportions in each of the three markets. If there is any bias towards banking, the index composition hints that at least it is consistent across the three countries. In the same spirit all three countries exhibit a similarly consistent trading pattern with respect to the U.S. and the old EU-15.

Further, we compiled an extensive data set on 15 different macroeconomic announcements (news) that are divided into four categories. These are announcements on prices, real economy (GDP, current account, production, sales, trade balance, unemployment, etc.), monetary policy (monetary aggregate and interest rate), and economic confidence (consumer and industry confidence, business climate, etc.). We provide details on the types and origin of the announcements later in this section.

The macroeconomic announcements we employ are surveyed by Bloomberg and Reuters with a clearly defined calendar and timing of the news releases; as publication schedules of the releases is publicly available we do not report it for the sake of space. The available information from Bloomberg and Reuters also contains internationally surveyed market expectations of the specific news that provides a market consensus on the expected values relevant for specific announcements. The surveyed values then constitute the internationally based proxy for market expectations, a similar to the one used for example in Andersen et al. (2007). In our analysis we consider all scheduled macroeconomic announcements but for estimation purposes we employ only the major releases. A complete set of announcements from the Bloomberg database allows us to isolate the timing of other (i.e. not employed in the analysis) announcements and therefore minimize possible bias 
stemming from the fact that market expectations are formed and announced only for the major announcements. ${ }^{6}$

The above arrangement is particularly important since it enables us to analyze the effect of the news from its excess impact perspective. Because markets form expectations about scheduled important news, it is not the news itself that matters but its difference from what the market expects it to be (market consensus). The news deviation, or its excess, has then an impending impact on stock prices. Following this logic, we construct a data set of announcements. There is news associated with indicator $i$ in the form of various macroeconomic releases or announcements that are known ahead of time to materialize on specific dates $t .^{7}$ The extent of such news is not known but expectations on the market form a forecast. The excess impact news announcement is then defined as a deviation of the news from the market expectation formed earlier. Further, announcements are often reported in different units and therefore they are standardized to allow their meaningful comparison (see e.g. Andersen et al., 2007). Formally, the excess impact news variable is labeled as $x n_{i t}$ and defined as $\left(s n_{i t}-\mathrm{E}_{t-1}\left[s n_{i t}\right]\right) / \sigma_{i}$, where $s n_{i t}$ stands for the value or extent of the scheduled announcement $i$ at time $t$ and $\mathrm{E}_{t-1}\left[s n_{i t}\right]$ is the value of the announcement for time $t$ expected by the market at time $t-1$, and $\sigma_{i}$ is the sample standard deviation of the announcement $i$. The standardization does not affect the properties of the coefficients' estimates as the sample standard deviation $\sigma_{i}$ is constant for any announcement indicator $i$.

From a practical perspective, we consider the immediate effect of each new announcement at the time of its release and account for its impact after 5 minutes. An extension of the interval up to 10 minutes does not yield an improvement because the impact of the scheduled announcements dissipates very quickly. This is consistent with observation that the significant differences in price discovery concentrate in transactions that immediately follow the news release (Greene and Watts, 1996). Following the excess impact approach described above, we differentiate the positive $(+)$ and negative (-) impact of the announcement in terms of its relation to market expectations. An announcement has a zero impact if it is exactly in line with the market or not further than $5 \%$ of the news sample

\footnotetext{
${ }^{6}$ The classification of news as a major announcement is based on a survey of international experts (Bloomberg) anticipating the given announcement. The survey works in this context as a market expectation for the particular announcement. By the same token we do not consider a time when no other macro announcement was made as "no news". Similarly like other researchers in the field, we are unable to account for announcements for which the market expectations are not formed and not made available.

${ }^{7}$ There is also news in the form of an unexpected announcement that can be understood as a truly exogenous shock or surprise. The number of such news that is recorded is negligible and we do not consider them in the present study.
} 
standard deviation from market consensus. ${ }^{8}$ The excess impact approach per se assumes that the difference of the announcement from its market expectation is in the form of a certain function (say linear or quadratic). Given the emerging character of the markets under research we simplify this assumption and consider only three types of impact: negative, in-line and positive. In this case our findings should be robust with respect to the particular excess impact response.

In our analysis we concentrate chiefly on foreign news originating in the Eurozone and the U.S.A. because the majority of local news is released intentionally before the market opening and thus they are absorbed by the market before trading begins and they are factored into stock prices without delay. ${ }^{9}$ The time difference between the markets is accounted for by setting CEDT time for all news releases, which eliminates the time difference between the U.S. and continental Europe. The details on the announcements are introduced in Table 2. The first category contains prices measured by Consumer and Industry Price Indices (items 1 and 2). News on the real economy (items 3 to 9) covers industrial production, GDP, factory orders, retail sales, trade balance, current account, and unemployment. Monetary indicators (items 10 and 11) are represented by the money aggregate and central banks' key interest rates. The category business climate and consumer confidence contains four measures (items 12 to 15). The first two are official indicators of the business climate and consumer confidence that provide an assessment of the current and expected business situation by surveying companies and the degree of optimism about the current and future state of the economy by surveying consumers. Then, there are two indices published by the Institute for Supply Management (ISM) in the U.S. and their equivalents for the Eurozone. These are the ISM index on business activities (non-manufacturing) and the Purchasing Managers' Index (PMI). Both indices are widely used by financial analysts and traders worldwide. ${ }^{10}$

\footnotetext{
${ }^{8}$ As a robustness check, we consider a set of news that deviates from market expectations by $\pm 10 \%$. In this case estimates differ, though. We believe that the threshold of $\pm 10 \%$ is too distant from the market consensus and the interval includes announcements with excess values that come as a true surprise and distort estimates as compared to an interval of $\pm 5 \%$.

${ }^{9}$ In all three markets the overwhelming majority of the important news (e.g., GDP or inflation) is released before trading begins and therefore the markets have time to absorb the information prior to the trading session. This institutional arrangement means that the market opening already reflects the announcements to a large extent. Most of the news then comes as no surprise since they are in line with market expectations and because they are processed even before trading begins, their effect is dampened dramatically. Among the few local news that are released during the trading hours are the interest rate decisions made by central banks. In this case their values are virtually always in-line with market expectations and this type of news comes then as no surprise on the markets. In any event, estimations that accounted for local news did not provide any significant results. For this reason we report only results with foreign news. Information on the release of domestic announcements is provided in Table A1 in the Appendix.

${ }^{10}$ In our analysis we intentionally omit any type of news related to microeconomic foundations, such as company economic results, government regulation changes pertaining to major companies, etc. This is done for
} 
The link from the announcement type to its effect on stock prices is not always clear and depends on how market perceptions reflect specific macro-financial linkage. This difficulty has been pointed out and the general consensus in the literature is that macroeconomic announcements have significant effects on financial markets, both in terms of asset returns and their volatility, but the impact of the announcements, specifically on volatility, is generally ambiguous as documented by Andritzky, Bannister and Tamirisa (2007) on emerging bond markets. Moreover, the theoretical framework linking macro announcements to stock returns is underdeveloped. ${ }^{11}$ For this reason we spell out in Table 2 the economic hypotheses on the impact of specific types of macroeconomic announcements as they are researched in the relevant empirical literature, examples of which we cite along with each hypothesized impact effect. The hypothesized effects of foreign macroeconomic announcements on stock prices are formulated for cases when the actual value of an announcement exceeds market expectations. In the majority of cases the announcement has a positive (negative) impact if it is above (below) market expectations. For example, a news release about, say, 3.5\% GDP growth under a market expectation of $2.5 \%$ will be considered a positive surprise of $1 \%$. However, there are some announcements where the impact direction is reversed. For example, empirics suggest that a higher-than-expected unemployment rate has a negative impact as its consequence means higher tax collection, decreased payments from the state, etc. Similarly, higher-than-expected inflation and interest rates have a negative impact as they represent higher prices and more expensive credit.

In Table 3 we show, separately for each market, the scope and distribution of news announcements entering the three stock markets during their respective trading hours. In Prague (9:30 to 16:00 CEDT), there is total of 536 U.S. announcements for the period under research. News with negative, in line, and positive impact are roughly in a ratio of 3:1:3 in total, but proportions differ across news types. Announcements on unemployment are represented most frequently, followed by those on prices, real economy activities, and business confidence. The Eurozone news group is represented by 899 announcements and contrary to the U.S., all three types of news enter the market in almost equal proportions. News on business confidence, prices, and real economy are the most frequent. The Eurozone

practical reasons. The availability of this type of data and the exact timing of the information releases are extremely difficult.

${ }^{11}$ We refer readers to the account of bond pricing with announcement effects of Piazzesi (2001), the equities modeling framework with announcement effects of Mamaysky (2002), and the equilibrium asset pricing model with public announcements by Cenesizoglu (2007). 
announcements are more evenly distributed among various types than U.S. news because the trading hours overlap with Central European markets is much larger.

Budapest stock market operates the longest trading session among the three new EU markets (9:00-16:30 CEDT). Budapest receives the broadest sample of news due to the longest span of the trading session. There are 700 announcements originating in the U.S. and those with negative/positive impact are equal in number (307/307). Only about $11 \%$ of announcements are in line with market expectations. The distribution of the announcements is similar to that in Prague. Unemployment announcements is the single most frequent category, followed by prices. Representation of Eurozone news totals 934 announcements, with negative and positive impacts carrying almost equal weights (315/320).

Finally, the trading session in Warsaw is the shortest among the countries (10:0016:00 CEDT) and that is why the number of foreign news announcements is also the smallest. The numbers of the announcements originating in the U.S. and Eurozone are 535 and 731, respectively. Their division among various types is naturally similar to that in Prague and Budapest.

\subsection{Estimation Methodology}

We employ the augmented generalized autoregressive conditional heteroskedasticity (GARCH) model attributed to Bollerslev (1986) to empirically test for the effect of macroeconomic announcements on stocks and to assess stock market volatility. We augment the mean specification by parameters to account for the effect of macroeconomic news in the form of deviations of scheduled releases from market expectations and the effects of spillovers from neighboring emerging markets as well as two major developed markets (Germany and the U.S.). ${ }^{12}$ The volatility equation is augmented by a set of dummy variables to capture intraday and daily effects. Thus, our model effectively captures the effect of news and market spillovers on stock returns and the effect of trading patterns on stock volatility. The baseline model is specified in the following form:

$$
R_{i, t}^{E}=\sum_{y=2004}^{2007} \lambda_{y}+\sum_{k \in\{E U, U S\}} \sum_{j=1}^{p} \pi_{k} R_{k, t-j}^{M}+\sum_{i=1}^{2} \sum_{j=1}^{q} \gamma_{i} R_{i, t-j}^{E}+\sum_{j=1}^{n} \sum_{l=1}^{3} \delta_{l, j} x n_{E U}^{j}+\sum_{j=1}^{n} \sum_{l=1}^{3} \kappa_{l, j} x n_{U S}^{j}+\varepsilon_{t}
$$

\footnotetext{
${ }^{12}$ Since macroeconomic announcements qualitatively vary, the exponential or threshold GARCH models would also be an adequate option. These models accommodate asymmetry in that negative shocks can have a bigger impact on volatility than positive shocks. Since we specifically categorize news variables as negative, positive or neutral, by including them in our specification we capture the asymmetric effect of the news in more detail than in threshold or exponential models. For this reason we opted for the specification employed in this paper.
} 


$$
h_{i, t}=\omega+\sum_{m=1}^{r} \alpha_{m} \varepsilon_{t-m}^{2}+\sum_{m=1}^{s} \beta_{m} h_{i, t-m}+\sum_{\tau \in T} \mu_{\tau} D_{\tau}+\sum_{d=1}^{4} \psi_{d} W_{d}
$$

The variables in the mean equation (1) are coded as follows. Our dependent variable $R_{i, t}^{E}$ is the return on a specific emerging $(E)$ market stock index $i$ (Budapest, Prague, Warsaw) at time $t$. The parameter $R_{k, t-j}^{M}$ is the lagged return on a specific mature and developed $(M)$ stock market index in the European Union (EU) and the United States (US). As a proxy for the Eurozone we employ the German DAX index from the Frankfurt stock exchange and for the U.S.A. we employ the Dow Jones Industrial Average of 30 stocks index. ${ }^{13}$ Coefficients $\pi_{k}$ capture the effects of market spillovers from the two developed markets. The parameter $R_{i, t-j}^{E}$ is the lagged return on a specific emerging market stock index other than that employed as a dependent variable and coefficients $\gamma_{i}$ capture the effects of spillovers from emerging markets (e.g., in the case of the Prague index being the dependent variable, lagged indices from Budapest and Warsaw are right-hand side variables). Coefficients $\lambda$ represent a set of yearspecific dummy variables that provide information on stock index returns in a specific year during the period 2004-2007.

A vector of the news announcements defined in section 2.1 is denoted as $x n_{E U}^{j}$ for the announcements originating in the Eurozone $(E U)$ and $x n_{U S}^{j}$ for those originating in the U.S.A. $(U S)$. Further, subscript $j$ indexes news announcements according to their type or class that we described in section 2.1 and classified in Table 3. Finally, subscript $l$ indexes the three qualities of the news entering our specification. This way we are able to disclose a different reaction expected from a behavioral point of view to announcements that are below market expectations (excess negative news, $\delta_{1, j}$ ), announcements that are in-line with market assessment (news with no-impact, $\delta_{2, j}$ ), or announcements above market expectations (excess positive news, $\delta_{3, j}$ ). Thus, coefficients $\delta_{l, j}$ capture the contemporaneous effects of various types of news on stock index returns. The numbers of lags $p$ and $q$ are equal to 2 and were chosen by the lag selection information criteria; lags are indicated in Tables 5-7. Hence, in terms of lag structure we estimate the same model that is consistent across the three markets. Finally, intercepts in different years captured by $\lambda_{y}$ are allowed to vary for the sake of filtering away effects of potentially different means during the consecutive years.

\footnotetext{
${ }^{13}$ Germany is the most important trading partner for the three new EU countries under research. Using a composite Stoxx 50 or EuroStoxx 50 index is not feasible as these are not available historically at the desired intra-day frequencies.
} 
The conditional variance $h_{i, t}$ specification (2) is of the $\operatorname{GARCH}(1,1)$ type with lags $r$ and $s$ chosen by the lag selection information criteria. The ARCH term, $\alpha \varepsilon_{t-1}^{2}$, primarily reflects the impact of news or surprises from previous periods that affect stock price volatility. A significant and positive value of $\alpha$ that is less than one characterizes the extent to which shocks do not destabilize volatility. When $\alpha$ is greater than one, shocks from the past are destabilizing. The GARCH term $\beta h_{t-1}$ measures the impact of the forecast variance from previous periods on the current conditional variance or volatility. Hence, a significant value for $\beta$ that is close to one indicates a high degree of persistence in stock price volatility. The sum of both coefficients, i.e., $\alpha$ plus $\beta$, indicates the speed of the convergence of the forecast of the conditional volatility to a steady state. The closer its value is to one, the slower the convergence.

Further, behavior on stock markets has been documented to follow periods of lower and higher activity during a trading day in the form of a $U$-shape pattern (e.g. Ekman, 1992; McMillan and Speight, 2002; Fan and Lai, 2006; and Égert and Kočenda, 2007). Such a pattern can be explained by the arrival and incorporation of news during the beginning of the trading session or by intraday trading activity as evidenced by Frijns and Margaritis (2008), implying the opening and closing of positions at the beginning and at the end of the trading session. In order to avoid mixing periods of varying volatility our specification includes a dummy variable $D_{\tau}$ associated with five-minute intraday intervals (ticks) at the beginning and end of the trading day. The associated coefficients $\mu_{\tau}$ capture intraday volatility whose presence has been documented in the literature for quite a time (see Andersen and Bollerslev, 1998). The volatility at the beginning and end of the trading session is considerably higher than during the rest of the trading day and this decline in volatility is captured by the constant $\omega$. The range of intraday dummies was selected based on the results of the likelihood ratio test. We ran regressions with and without these dummies and used standard LR statistics to discriminate between the two specifications. We opted for the one that includes dummies. Finally, dummy variable $W_{d}$ allows accounting for the effect of specific days during a business week. Four coefficients $\psi_{d}$ capture these day-of-the-week effects well documented in the empirical literature including European markets (see e.g. Tonchev and Kim, 2004; Chang, Pinegar and Ravichandran, 1993; Kiymaza and Berument, 2003). To sum up, the volatility 
specified by equation (2) represents a simple yet comprehensive specification allowing for assessment as well as the influence of trading patterns on volatility. ${ }^{14}$

Based on the Akaike information criterion, the Schwarz-Bayesian information criterion and the significance of the coefficients, we select a specific version of the baseline model that corresponds best to the data on each stock index. The standardized residuals from such a specification are free from ARCH effects. Estimation of the model uses a loglikelihood function, $\ln L_{t}=-0.5\left(\ln \left(2 \pi h_{t}\right)+\sum_{t=t_{0}}^{T} \varepsilon_{t}^{2} / h_{t}\right)$, as in Bollerslev (1986). The maximum-likelihood estimates are obtained by using the numerical optimization algorithm described by Berndt et al. (1974). To avoid the risk of overestimating volatility, we do not impose the normality condition on the distribution of errors. Rather, we allow for generalized error distribution (GED) following Nelson (1991). The volatility of stock prices is likely to follow a leptokurtic data distribution that is reflected by an actual GED parameter considerably lower than 2 , which is the value in the case of normal distribution. Leptokurtosis implies that daily stock price volatility tends to concentrate around the mean during tranquil market periods but that shocks to volatility are large during turbulent times.

The above specification accounts for the effect of various types of news on the firms' market value, hence the value of the market index. The emerging European stock markets are documented to be influenced by EU news but also by U.S. macroeconomic announcements at 14:30 CEDT and by the opening of the U.S. stock market at 15:30 CEDT. The news announcements from these two regions are hypothesized to exhibit the most direct influence on the new EU stock markets. The specification also accounts for the spillover effects through the lagged index returns of neighboring emerging stock markets as well as lagged German and U.S. returns. Since trading hours in different markets span over different time periods we treat this difference by estimating the set of mean and volatility equations for each of the three emerging markets separately.

\section{Empirical Findings}

The results of our analysis are presented in Tables 4-6 for each of the three countries separately. Each table is divided into two panels. Panel A displays the estimates of the spillover effects in the mean equation as well as estimates from the volatility equation. The effects of specific news in the mean equation are then summarized in panel B. Each effect of

\footnotetext{
${ }^{14}$ We do not include macro news in the variance equation primarily because of identification restrictions. Another reason is that our primary aim is to analyze the effect of news on returns, following the approach of Andersen, Bollerslev, Diebold and Vega (2007).
} 
an announcement is clearly identified by the associated coefficients $\delta_{l, j}$ and $\kappa_{l, j}$ for Eurozone and U.S. news, respectively. For example, coefficient $\delta_{3,1}$ shows the effect of the industrial production announcement (subscript 3) originating in the Eurozone whose value is below market expectations (subscript 1), and coefficient $\kappa_{1,2}$ shows the effect of an announcement of the consumers prices (subscript 1) originating in the U.S.A. that is in line with market expectations (subscript 2).

Our results show substantial spillovers affecting the new EU markets together with the news impact on the index returns in general. The German DAX exhibits the strongest spillover effects, followed by the Dow-Jones and regional indices whose impact varies. The impact of announcements differs with respect to the extent and origin of the news as well as the impacted stock market. We credit these differences to the varying extent of foreign, mostly institutional, investors on the three markets and their shares on traded volumes. These investors are active in all segments and do not lean towards particular sectors. The presence of foreign investors on the Czech and Hungarian markets is heavy and varies around 55-60\% and $75 \%$ of the traded volume, respectively, over time. ${ }^{15}$ The Hungarian market is dominated by investors from the old EU while U.S. investors prevail on the Czech market. This is in sharp contrast to the Polish market where only about one third of the traded volume is due to foreign investors. Different perceptions and sensitivity to news origin are conjectured as reasons behind the differences in our results. ${ }^{16}$

The general finding can be interpreted according to efficient market theory. Significant coefficients associated with the impact of the news testify that the announcements are not absorbed by the market immediately and not reflected instantaneously in prices. This is evidence of market inefficiency. Announcements originating in the Eurozone exhibit more effects than U.S. news. In terms of specific news, EU current account, consumer confidence and PMI affect all three markets while U.S. prices are the only news of the same reach. The volatility of the returns is accounted for at the beginning and end of the trading session and it declines dramatically during the rest of the day. The differences in the extent of volatility at

\footnotetext{
${ }^{15}$ We are grateful to the Prague Stock Exchange (PSE) for the results of the analysis on the structure of investors and for information on the proportion of foreign investors on the Czech capital market. We are also indebted to the PSE for facilitating similar information collection from the Budapest and Warsaw stock exchanges.

${ }^{16}$ We rule out the different trading hours as the cause of the different results across the markets. When constraining the data sample to the common trading window as in Hanousek, Kočenda, and Kutan (2009) the differences remained of the same extent.
} 
the three markets should be credited to differences in trading hours on these markets. This finding is consistent with results of French and Roll (1986) and Banko and Flannery (2008). ${ }^{17}$

\subsection{Czech Republic}

The returns on the Prague stock index PX-50 (Table 4.A) reflect most heavily spillovers from Frankfurt $\left(\pi_{1}\right.$ and $\left.\pi_{2}\right)$ whose impact is double that of Dow-Jones $\left(\pi_{3}\right.$ and $\left.\pi_{4}\right)$. Regional spillovers are smaller but comparable to the U.S. spillovers and they come from Budapest $\left(\gamma_{1}\right.$ and $\left.\gamma_{2}\right)$ as coefficients on the Polish index are either insignificant $\left(\gamma_{5}\right)$ or small $\left(\gamma_{6}\right)$. All spillovers are positive and hint at the market being efficient but this finding is contested by the multiple effects of news announcements (Table 4.B). Among these the effects of prices and real economic indicators from the Eurozone stand out. A positive outcome of consumer price development has a positive effect on the stock index return $\left(\delta_{1,3}\right)$, while less favorable announcements below market expectations on industrial production $\left(\delta_{3,1}\right)$, current account $\left(\delta_{8,1}\right)$, and unemployment $\left(\delta_{9,1}\right)$ all exhibit negative effects on stock returns. ${ }^{18}$ Further, the effect of a consumer confidence release that is in line with the market shows a negative impact $\left(\delta_{13,2}\right)$. Higher-than-expected growth in the Purchasing Managers' Index (PMI) exhibits a positive impact $\left(\delta_{15,3}\right)$ on stock returns while a value that is in line with the market assessment shows negative impact of similar extent $\left(\delta_{15,2}\right)$. While the positive impact of positive news does not pose an intellectual challenge, the negative impact of the in-line outcome of consumer confidence and PMI is not clear. A possible interpretation is that markets expect a specific value of a particular indicator but hope for a better result, which turns an in-line outcome into negative news. This interpretation also fits with the empirical facts that negative news impacts stocks more than positive news of the same caliber; the same result is found by Kaminsky and Schmukler (1999) on Asian emerging markets.

The only announcements originating in the U.S. that impact index returns are consumer and producer prices. A favorable development in producer prices has a positive impact $\left(\kappa_{2,3}\right)$ while consumer prices that are in line with expectations exhibit a negative impact $\left(\kappa_{1,2}\right)$. The findings show that the market index is affected by spillovers from other

\footnotetext{
${ }^{17}$ French and Roll (1986) show that volatility is not fixed across calendar time intervals but varies with trading time. The variability of trading hours has increased since the mid-1980s. Banko and Flannery (2008) find that permanent changes in the available trading hours on the U.S. stock market can fully account for the increase in volatility from 1962 to 2004.

${ }^{18}$ The finding of the negative effect of unemployment goes against the results of Boyd, Hu and Jagannathan (2005) who find that on average, an announcement of rising unemployment is good news for stocks during economic expansions and bad news during economic contractions. During the period under research the Czech Republic as well as Hungary and Poland were in an expanding period of the business cycle. For this reason we also do not adjust our estimation to account for different stages of business cycle.
} 
markets as well as specific news where most of the announcements exhibit an intuitively correct impact on the return. This finding rules out market efficiency in the sense of the strict theoretical definition.

The above results are complemented by the volatility equation estimates (Table 4.A). The ARCH term $\alpha \varepsilon_{t-1}^{2}$ reflects the impact of news or surprises from previous periods that affect stock price volatility. The size of the coefficient $\alpha$ indicates that past announcements affect volatility to an extent but they do not destabilize volatility. On the other hand, the $\beta$ coefficient in the GARCH term, $\beta h_{t-1}$, is quite small and indicates that the impact of the forecast variance from previous periods on the current conditional variance, or volatility, is not persistent. Finally, the fact that the sum of both coefficients, i.e., $\alpha$ plus $\beta$, is way below one indicates that the convergence of the conditional volatility to a steady state is very fast. A large negative constant $(\omega)$ in conjunction with significant coefficients of the intra-day volatility dummies $\left(\mu_{1}-\mu_{10}\right)$ illustrate the sizable decrease of the volatility during the middle of the trading day. Intra-day volatility dummies capture increased volatility during the beginning and end of the trading session and their inclusion accounted for the differences in volatility during the trading day. Day-of-the-week dummies contribute to the volatility in relatively even proportions $\left(\psi_{1}, \psi_{2}, \psi_{4}\right)$ but its extent decreases by the middle of the week $\left(\psi_{3}\right)$.

\subsection{Hungary}

The Hungarian stock index exhibits considerable spillover effects (Table 5.A) from the other two regional markets; the spillovers are of unequal magnitudes and the effect of the Prague market dominates that of Warsaw. In the first lag the Prague effect $\left(\gamma_{3}\right)$ is about five times stronger than that of Warsaw $\left(\gamma_{5}\right)$, but their second lags' effects are equal $\left(\gamma_{4}\right.$ and $\left.\gamma_{6}\right)$. On the contrary, the first lag impact of the Frankfurt and New York markets are of equal caliber $\left(\pi_{1}\right.$ and $\pi_{3}$ ) but only Frankfurt retains further influence $\left(\pi_{2}\right)$.

The Hungarian index is also impacted by the number of announcements whose majority originates in the Eurozone and they generate the following impacts (Table 5.B). In terms of news from the real economy, announcements on GDP and trade balance that are in line with market expectations prompt positive $\left(\delta_{4,2}\right)$ and negative $\left(\delta_{7,2}\right)$ effects on stock market index returns, respectively. Better-than-market announcements on current account development generate a positive effect $\left(\delta_{8,3}\right)$, while lower-than-market results on unemployment are reflected in a negative impact on stock returns $\left(\delta_{9,1}\right)$. Survey indicators on the climate and confidence regarding the EU economy provide unambiguous interpretations. 
A lower-than-expected consumer confidence indicator triggers a negative effect $\left(\delta_{13,1}\right)$ while in-line or better-than-market developments of the Purchasing Managers' Index (PMI) yield positive effects $\left(\delta_{15,2}\right.$ and $\left.\delta_{15,3}\right)$.

Further, past news $(\alpha)$ affects volatility to a moderate extent and they are not destabilizing (Table 5.A). The volatility of the Hungarian stock index exhibits the highest persistence (indicated by the value of the GARCH term $\beta h_{t-1}$ ) among the three indices. Finally, the speed of the convergence of the forecast of the conditional variance to a steady state is very slow. The change in intra-day volatility is fully accounted for $\left(\mu_{1}-\mu_{10}\right)$ and its decline is substantial $(\omega)$, similarly as in the other two markets. Intra-week volatility increases only in the middle of the week $\left(\psi_{3}\right)$, otherwise it stays comparably low $\left(\psi_{1}, \psi_{2}, \psi_{4}\right)$. High and persistent volatility on the Hungarian market, which has the largest proportion of foreign investors, is in line with the findings of Wang (2007), who documents the significant impact of foreign investors on returns and volatility in some Asian markets.

\subsection{Poland}

From Table 6.A we see that the Polish stock index is affected by spillovers from key world as well as regional markets. The effect of the Frankfurt market $\left(\pi_{1}\right.$ and $\left.\pi_{2}\right)$ is larger and more prolonged than that of the U.S. $\left(\pi_{3}\right)$. In a similar manner the effect of Prague $\left(\gamma_{3}\right)$ is smaller and less extended than that of Budapest $\left(\gamma_{1}\right.$ and $\left.\gamma_{2}\right)$. The impact of spillovers is complemented by numerous effects of news (Table 6.B). In terms of prices, there is no effect from the Eurozone but an important and intuitively meaningful effect of U.S. announcements. Belowmarket development in consumer prices is reflected by a negative impact $\left(\kappa_{1,1}\right)$ while movement in producer prices better than market expectations impacts stock returns positively $\left(\kappa_{2,3}\right)$. At the same time, producer prices in-line with market assessment impact the stock index negatively $\left(\kappa_{2,2}\right)$, a sign of the tendency of markets to undervalue positive changes. The impact of real economy announcements on stock returns depends on the region of origin. Above-market progress in industrial production $\left(\delta_{3,3}\right)$ and current account $\left(\delta_{8,3}\right)$ in the EU results in a positive effect $\left(\delta_{3,3}\right.$ and $\left.\delta_{8,3}\right)$. In-line announcements on retail sales and trade balance in the U.S. are reflected in a strong and positive effect $\left(\kappa_{6,2}\right.$ and $\left.\kappa_{7,2}\right)$ while in-line unemployment brings a negative impression $\left(\kappa_{9,2}\right)$ on the index return. Survey indicators produce adequate reactions no matter in which region they originate but the impact of U.S. news is less frequent than that of the Eurozone. The EU consumer confidence announcements that are below and above market expectations produce negative $\left(\delta_{13,1}\right)$ and positive $\left(\delta_{13,3}\right)$ 
effects of comparable extent, respectively. Further, lower-than-expected growth in the Purchasing Managers' Index (PMI) from the U.S. negatively impacts $\left(\kappa_{15,1}\right)$ stock returns while its above-EU market outcome shows a positive effect $\left(\delta_{15,3}\right)$. Finally, in-line movement in the Eurozone monetary aggregate is echoed by a negative influence on stock returns $\left(\delta_{10,2}\right)$.

In terms of volatility (Table 6.A), from the value of the coefficient associated with the $\mathrm{ARCH}$ term $(\alpha)$ we find that past news affects volatility to the lowest extent among all three markets and also in a non-destabilizing manner. Further, the volatility of the Polish stock index exhibits the middle persistence $(\beta)$ with respect to its regional counterparts. Similarly to the Budapest index returns, the speed of the convergence of the forecast of the conditional variance to a steady state is relatively fast but much slower than in the case of Prague. Intraday volatility dummies account well for the volatility during peak trading periods $\left(\mu_{1}-\mu_{7}, \mu_{9}\right.$ $\left.-\mu_{10}\right)$ and a sizable negative value of constant $(\omega)$ reflects a dramatic decline in volatility during the trading session. Day-of-the-week dummies contribute to the volatility in relatively even proportions $\left(\psi_{1}, \psi_{2}, \psi_{4}\right)$, with a decrease by the middle of the week $\left(\psi_{3}\right)$.

\subsection{Robustness Check}

As a robustness check we also performed estimations with local news originating at the three markets. These announcements are intentionally made before trading begins in most cases. For example there is only a single announcement emerging during trading hours at the Budapest stock market. More local news is present during trading at markets in Prague and Warsaw but their extent is marginal when compared to those coming from the Eurozone and the U.S. In any event, the effect of local news is mostly insignificant and for that reason we do not report them. Additionally, by not employing a handful of the local news we further minimize the bias and improve the identification of the effect of the Eurozone and the U.S. announcements on the stock returns.

\section{Concluding Summary}

We analyze spillovers and the effect of macroeconomic news on three emerging EU stock markets: the Czech Republic, Hungary, and Poland. In our analysis we employ highfrequency five-minute intraday data of stock market index returns. We analyze the effect of the four classes of Eurozone and U.S. macroeconomic announcements from the excess impact perspective, e.g. we account for the difference of each announcement from its market expectation. Further, we jointly model the volatility of the returns accounting for its intra-day 
movements as well as day-of-the-week effects. Our main contribution is that we are able to show the exact sources of macro news spillovers from the developed foreign markets to the three new EU markets under research.

Despite varied effects inferred from estimates we can draw some generalizations specific to all three countries. The effects of other stock markets are dominated by spillovers from Frankfurt stock exchange while reaction to the New York market is smaller. The findings are sensible given the ongoing process of European integration that also affects financial markets and the narrow time window during which trading at the U.S. and European markets overlap. Spillovers from the neighboring markets are smaller or comparable in cumulative magnitudes to the effect of New York. Among them the Budapest stock market produces the strongest spillover effects, possibly due to the largest volume of trade conducted by foreign investors, followed by Prague, and the smallest effect is from Warsaw.

The effects of macroeconomic announcements need more detail to summarize. Among the four classes of macroeconomic announcements, monetary news has virtually no impact on stock returns. The reason might rest in the relative detachment of monetary policy figures from stock market developments. Rigobon and Sack (2006) claim that the "detachment" of monetary policy expectations and asset prices from incoming economic news is partly related to the difficulties associated with measuring the surprise component of that news. Since we account for the surprise component our findings show that the detachment might be due to the low value stock markets place on monetary announcements.

Prices on the other hand affect all three markets, mostly in a very intuitive manner: worse (better) than expected results bring negative (positive) effects on stock returns. This result upholds the market's ability to effectively incorporate inflation into stock prices. The interesting trait in the price effect findings is the dominating influence of U.S. prices while the Eurozone announcements pass nearly unnoticed. ${ }^{19}$ The possible and sensible explanation might be credited to the well-mapped expectations of the European Central Bank's operations that in the integrating Europe pose little challenge to financial market assessment. Steps taken by the Federal Reserve on the other hand may come as a surprise more often. Further, Jankov et al. (2008) have found that inflation in many countries in CEE is very strongly affected by the USD/EUR rate, even though the weight of trade in U.S. dollars seems to be rather low and central banks use the Euro as a reference currency. Awareness of markets about the above facts may, at least partially, explain our findings.

\footnotetext{
${ }^{19}$ The importance of the consumer and producer price information on the U.S. market found by Kim, McKenzie and Faff (2004) is in line with our findings.
} 
The real economy class of announcements offers varied results from which the news on the EU current account stand out as it affects all three markets in the same manner without exception: better-than-expected results prompt a positive reaction and worse-than-expected results prompt a negative one. This finding should be paired with the heavy dependency of the three economies on foreign trade with other EU countries, the presence of EU firms in these markets, the similarity of supply and demand shocks (Fidrmuc and Korhonen, 2003), and a relatively high degree of business cycle correlation (Fidrmuc and Korhonen, 2006) between the old and new EU members. Needless to say that the most important companies present in the new EU economies as owners or co-owners of the major local firms and banks are also often quoted on the local stock markets. Other real economy announcements are limited in their reach to one or two markets. Industrial production influences Prague and Warsaw, while announcements on trade balance and unemployment are echoed in Prague and Budapest. Announcements on factory orders and retail sales do not provoke any market reactions. Real economy announcements originating in the U.S. bring only scarce evidence of their effects on stock returns. Many announcements are simply not available during the Europe-U.S.A. trading window. The Prague stock market is not affected by U.S. news at all while Budapest and Warsaw are only sparingly.

Finally, business climate and confidence announcements provide valuable insights to the previous categories. Practically no effect of the U.S. survey announcements has been found in any of the three markets and the effect of those originating in the Eurozone is limited. Only the news on consumer confidence and the Purchasing Manager's Index (PMI) impact all three markets in an intuitive manner common to developed markets: a worse-than-expected outcome provokes a negative effect on stock returns and better-than-expected results prompt a positive one. All the above results thus validate the excess impact approach that highly reduces difficulties in measuring "news" correctly.

News affects the volatility of the stock return indices in a similar manner but specific features vary across the three markets. The volatility of the Prague index is affected by the past announcements most but in no market is the effect destabilizing. The Budapest index exhibits the highest persistence of volatility. The volatility of the Warsaw index shows the slowest convergence to the steady state. In terms of the intra-day features the Budapest market exhibits the highest volatility at the beginning and end of the trading sessions while Prague records the lowest volatility during the two periods. Volatility declines dramatically on the three markets during the rest of the trading day and its extent is comparable across the 
markets. All three markets also show a decrease in volatility by the middle of the business week.

Our findings show that intraday interactions on the new EU markets are strongly determined by the macroeconomic news originating from mature stock markets. The differences in results across the three markets seem to be driven by differences in the composition and origin of the key market participants. The discovered detailed effects are complemented by a characterization of market volatility. Our findings yield insights into the process of the development of new European capital markets and stock market integration in the EU. ${ }^{20}$ As these new markets become more mature and globally integrated they become more important for the real economy of specific countries. Information flows related to developed economies, their ups and downs, were shown to affect emerging European capital markets, whose developments then affect the real economy. This is because smaller emerging markets are quite sensitive to changes in the economic situation in developed markets as well as to changes in perceptions that are conveyed via macroeconomic news. As the recent financial problems unfold globally, we can expect increases in sensitivity to the information flows reaching emerging markets and the need to understand them better.

\footnotetext{
${ }^{20}$ Comovements of the stock markets in the Czech Republic, Hungary, and Poland are studied by Scheicher (2001) and Égert and Kočenda (2010).
} 


\section{References}

Albuquerque, Rui and Clara Vega, "Asymmetric Information in the Stock Market: Economic News and Co-movement," CEPR Discussion Paper 5598(2006).

Alegria, Carlos, George McKenzie and Simon Wolfe, "Earnings Announcements by UK Companies: Evidence of Extreme Events?," European Journal of Finance 15(2009):137156.

Andersen, Torben G. and Tim Bollerslev, "Deutsche Mark-Dollar Volatility: Intraday Activity Patterns, Macroeconomic Announcements, and Longer Run Dependencies," Journal of Finance 53(1998): 219-65.

Andersen, Torben G., Tim Bollerslev, Francis X. Diebold, and Clara Vega, "Real-time Price Discovery in Global Stock, Bond and Foreign Exchange Markets," Journal of International Economics 73(2007):251-277.

Andritzky, Jochen R., Geoffrey J. Bannister, and Natalia T. Tamirisa, "The Impact of Macroeconomic Announcements on Emerging Market Bonds," Emerging Markets Review 8(2007):20-37.

Banko, John and Mark Flannery, "The Relation between Trading Time and Volatility: What is a "Day"?," Working Paper Series, University of Florida, (2008).

Berndt, Ernst K., B. H. Hall, R. E. Hall, and Jerry A. Hausman, "Estimation of Inference in Nonlinear Structural Models," Annals of Economic and Social Measurement 4(1974):653665.

Bohl, Martin T. and Harald Henke, "Trading Volume and Stock Market Volatility: The Polish Case," International Review of Financial Analysis 12(2003):513-25.

Bollerslev, Tim and Jun Cai, "Intraday and Interday Volatility in the Japanese Stock Market," Journal of International Financial Markets, Institutions, and Money 10(2000):107-130.

Bollerslev, Tim, "Generalized Autoregressive Conditional Heteroscedasticity," Journal of Econometrics 31(1986):307-327.

Bomfim, Antulio N., "Pre-announcement Effects, News Effects, and Volatility: Monetary Policy and the Stock Market," Journal of Banking and Finance 27(2001):133-151.

Boyd, John H., Jian Hu, and Ravi Jagannathan, "The Stock Market's Reaction to Unemployment News: Why Bad News Is Usually Good for Stocks," Journal of Finance 60(2005): 649-672.

Bredin, Don, Stuart Hyde, Dirk Nitzsche, and Gerard O'Reilly, "European Monetary Policy Surprises: The Aggregate and Sectoral Stock Market Response," Economic Analysis and Research Department Working Paper, Central Bank and Financial Services Authority of Ireland, No. 10/RT/2005(2005).

Cenesizoglu, Tolga, "Risk and Return Reaction of the Stock Market to Public Announcements about Fundamentals: Theory and Evidence," HEC Montreal, Department of Finance Working Paper (2007).

Černý, Alexandr and Michal Koblas, "Stock Market Integration and the Speed of Information Transmission: the Role of Data Frequency in Cointegration and Granger Causality Tests," Journal of International Business and Economics 1(2005):110-120.

Chang, Eric C., J. Michael Pinegar, and R. Ravichandran, "International Evidence on the Robustness of the Day-of-the-Week Effect," Journal of Financial and Quantitative Analysis 12(1993):497-513.

Égert, Balázs and Evzen Kočenda, "Time-Varying Synchronization of the European Stock Markets," Forthcoming in Empirical Economics (2010).

Égert, Balázs and Evzen Kočenda, "Interdependence between Eastern and Western European Stock Markets: Evidence from Intraday Data,” Economic Systems 31(2007):184-203. 
Ehrmann, Michael and Marcel Fratzscher, "Global Financial Transmission of Monetary Policy Shocks,” European Central Bank Working Paper, No. 616(2006).

Ehrmann, Michael and Marcel Fratzscher, "Taking Stock: Monetary Policy Transmission to Equity Markets," Journal of Money, Credit and Banking 36(2004):719-37.

Ekman, Peter D., "Intraday Patterns in the S\&P 500 Index Futures Market," Journal of Futures Markets 12(1992):365-381.

Erenburg, Grigori, Alexander Kurov, and Dennis Lasser, "Trading Around Macroeconomic Announcements: Are All Traders Created Equal?," Journal of Financial Intermediation 15(2005):470-493.

Fan, Yu-Ju and Hung-Neng Lai, "The Intraday Effect and the Extension of Trading Hours for Taiwanese Securities," International Review of Financial Analysis 15(2006):328-347.

Fidrmuc, Jarko and Iikka Korhonen, "Meta-Analysis of the Business Cycle Correlation between the Euro Area and the CEECs," Journal of Comparative Economics 34(2006):518537.

Fidrmuc, Jarko and Iikka Korhonen, "Similarity of Supply and Demand Shocks between the Euro Area and the CEECs," Economic Systems 27(2003):313-334.

Flannery, Mark and Aris A. Protopapadakis, "Macroeconomic Factors Do Influence Aggregate Stock Returns," Review of Financial Studies 15(2002):751-782.

French, Kenneth R. and Richard Roll, "Stock return variances: the arrival of information and the reaction of traders," Journal of Financial Economics 17(1986):5-26.

Frijns, Bart, Dimitirs Margaritis, "Forecasting Daily Volatility with Intraday Data," European Journal of Finance 14(2008):523-540.

Funke, Norbert, Akimi Matsuda, "Macroeconomic News and Stock Returns in the United States and Germany," IMF Working Paper, No WP/02/239(2002).

Graham, Smith and Ryoo Hyun-Jung, "Variance Ratio Tests of the Random Walk Hypothesis for European Emerging Stock Markets," European Journal of Finance 9(2003):290-300.

Greene, Jason T. and Susan G. Watts, "Price Discovery on the NYSE and the NASDAQ: The Case of Overnight and Daytime News Releases," Financial Management 25(1996):19-42.

Gurkaynak, Refet, Brian Sack, and Eric Swanson, "Do Actions Speak Louder than Words?: The Response of Asset Prices to Monetary Policy Actions and Statements," Finance and Economics Discussion Series 2004-66, Federal Reserve Board, Washington, D.C.

Hanousek, Jan, Evzen Kočenda, and Ali M. Kutan, "The Reaction of Asset Prices to Macroeconomic Announcements in New EU Markets: Evidence from Intraday Data," Journal of Financial Stability, 5(2009):199-219.

He, Ling T. "Variations in Effects of Monetary Policy on Stock Market Returns in the past Four Decades," Review of Financial Economics 15(2006), 331-349.

Jankov, Ljubinko, Ivo Krznar, Davor Kunovac, and Maroje Lang, "The Impact of the USD/EUR Exchange Rate on Inflation in the Central and East European Countries," Comparative Economic Studies 50 (2008):646-662.

Jensen, Gerald R., Jeffrey M. Mercer, and Robert R. Johnson, "Business Conditions, Monetary Policy, and Expected Security Returns," Journal of Financial Economics 40(1996):213-237.

Jones, Brad, Chieng-Ting Lin, and Mansur M. Masih, "Macroeconomic Announcements, Volatility, and Interrelationships: An Examination of the UK Interest Rate and Equity Markets," International Review of Financial Analysis 14(2005):356-375.

Kaminsky, Graciela L. and Sergio L. Schmukler, "What Triggers Market Jitters?: A Chronicle of the Asian Crisis," Journal of International Money and Finance, 18(1999):537-560.

Kasch-Haroutounian, Maria and Simon Price, "Volatility in the Transition Markets of Central Europe," Applied Financial Economics 11(2001):93-105. 
Kim, Suk-Joong, Michael D. McKenzie, and Robert W. Faff, "Macroeconomic News Announcements and the Role of Expectations: Evidence for US Bond, Stock and Foreign Exchange Markets," Journal of Multinational Financial Management 14(2004):217-232.

Kiymaza, Halil and Berument Hakan, "The Day of the Week Effect on Stock Market Volatility and Volume: International Evidence," Review of Financial Economics 12(2003):363-380.

Korczak, Piotr and Martin T. Bohl, "Empirical Evidence on Cross-listed Stocks of Central and Eastern European Companies," Emerging Markets Review 6(2005):121-137.

Mamaysky, Harry, "A Model For Pricing Stocks and Bonds," Yale ICF Working Paper, No. 02-10(2002).

McMillan, David G., Alan E.H. Speight, "Intra-day Periodicity and Long-Run Volatility," Econometrica 59(2002):347-370.

Morgese-Borys, Magdalena, Petr Zemčík, "Size and Value Effects in the Visegrad Countries.

CERGE-EI Working Paper No. 391 (2009).

Murinde, Victor and Sunil Poshakwale, "Volatility in the Emerging Stock Markets in Central and Eastern Europe: Evidence on Croatia, Czech Republic, Hungary, Poland, Russia and Slovakia," European Research Studies 4(2001):73-101.

Nelson, Daniel B., "Conditional Heteroskedasticity in Asset Returns: "A New Approach. Macroeconomic News and Stock Valuation in Europe," Journal of Multinational Financial Management 14(1991):201-215.

Nikkinen, Jussi and Petri Sahlström, "Scheduled Domestic and U.S. Macroeconomic News and Stock Valuation in Europe," Journal of Multinational Financial Management 14(2004):201-215.

Nikkinen, Jussi, Mohammed Omran, Petri Sahlström, and Janne Äijö, "Global Stock Market Reactions to Scheduled U.S. Macroeconomic News Announcements," Global Finance Journal 17 (2006):92-104.

Patelis, Alex D, "Stock Return Predictability and the Role of Monetary Policy," Journal of Finance 52(1997):1951-1972.

Piazzesi, Monika, "An Econometric Model of the Yield Curve with Macroeconomic Jump Effects,” NBER Working Paper, No. W8246(2001).

Poshakwale, Sunil and Victor Murinde, "Modelling the Volatility in East European Emerging Stock Markets: Evidence on Hungary and Poland," Applied Financial Economics 11(2001):445-456.

Ramchander, Sanjay, Marc W. Simpson, and Harold Thiewes, "The Effects of Macroeconomic News on German Closed-End Funds," Quarterly Review of Economics and Finance, In Press(2006).

Rigobon, Roberto and Brian Sack, "Noisy Macroeconomic Announcements, Monetary Policy, and Asset Prices," NBER Working Paper, No. W12420(2006).

Rockinger, Michael and Giovanni Urga, "The Evolution of Stock Markets in Transition Economies," Journal of Comparative Economics 28(2000):456-472.

Scheicher, Martin, "The Comovements of Stock Markets in Hungary, Poland and the Czech Republic," International Journal of Finance and Economics 6(2001):27-39.

Serwa, Dobromil and Martin T. Bohl, "Financial Contagion Vulnerability and Resistance: A Comparison of European Stock Markets," Economic Systems 29(2005):344-362.

Siklos, Pierre L. and John Anusiewicz, "The Effect of Canadian and U.S. M1 Announcements on Canadian Financial Markets: The Crow Years," Journal of Economics and Business 50(1998):49-65.

Thorbecke, Willem, "On Stock Market Returns and Monetary Policy," Journal of Finance 52(1997):635-654. 
Tonchev, Dimitar and Kim Tae-Hwan, "Calendar Effects in Eastern European Financial Markets: Evidence from the Czech Republic, Slovakia and Slovenia," Applied Financial Economics 14(2004):1035-1043.

Tse, Yiuman, Chunchi Wu, and Allan Young, "Asymmetric Information Transmission between a Transition Economy and the U.S. Market: Evidence from the Warsaw Stock Exchange," Global Finance Journal 14(2003):319-32.

Wang, Jianxin, "Foreign Equity Trading and Emerging Market Volatility: Evidence from Indonesia and Thailand," Journal of Development Economics 84(2007):798-811.

Wongswan, Jon., "Transmission of Information across International Equity Markets," Review of Financial Studies 19(2006):1157-1189. 
Table 1

Descriptive statistics of new EU stock market index returns (2004-2007)

\begin{tabular}{cccccc}
\hline & $\begin{array}{c}\text { Number of } \\
\text { observations }\end{array}$ & Mean & Std. Dev. & Minimum & Maximum \\
\hline $\mathbf{2 0 0 4}$ & & & & & \\
\hline BUX & 11,904 & 0.0010 & 0.090 & -0.875 & 0.867 \\
\hline PX50 & 10,182 & 0.0024 & 0.064 & -0.628 & 0.789 \\
\hline WIG20 & 9,542 & 0.0004 & 0.106 & -1.055 & 0.923 \\
\hline $\mathbf{2 0 0 5}$ & & & & & \\
\hline BUX & 22,090 & 0.0001 & 0.126 & -1.125 & 0.898 \\
\hline PX50 & 19,180 & 0.0011 & 0.085 & -1.934 & 1.928 \\
\hline WIG20 & 17,608 & 0.0012 & 0.103 & -0.793 & 1.514 \\
\hline $\mathbf{2 0 0 6}$ & & & & & \\
\hline BUX & 21,168 & -0.0010 & 0.131 & -1.454 & 1.414 \\
\hline PX50 & 18,258 & -0.0007 & 0.096 & -3.547 & 3.549 \\
\hline WIG20 & 16,956 & -0.0006 & 0.136 & -1.143 & 1.126 \\
\hline $\mathbf{2 0 0 7}$ & & & & & \\
\hline BUX & 21,298 & -0.0016 & 0.108 & -3.437 & 3.550 \\
\hline PX50 & 18,868 & 0.0002 & 0.079 & -1.141 & 1.121 \\
\hline WIG20 & 17,318 & -0.0010 & 0.120 & -1.140 & 1.407 \\
\hline
\end{tabular}

Note: Returns as well as the associated descriptive statistics are shown in percentages. 
Table 2

Hypothetical effects of foreign macroeconomic announcements on stock prices

\begin{tabular}{|c|c|c|}
\hline Announcements & $\begin{array}{c}\text { Hypothetical effect when actual } \\
\text { value exceeds a market expectation }\end{array}$ & Reference \\
\hline \multicolumn{3}{|l|}{ Prices } \\
\hline $\begin{array}{l}\text { - CPI } \\
2 \text { - PPI }\end{array}$ & Negative effect & $\begin{array}{l}\text { Flannery and Protopapadakis } \\
(2002) \\
\text { Kim, McKenzie and Faff (2004) } \\
\text { Rigobon and Sack (2006) } \\
\text { Ramchander, Simpson and Thiewes } \\
\text { (2006) } \\
\text { Jones, Lin and Masih (2005) }\end{array}$ \\
\hline \multicolumn{3}{|l|}{ Economy } \\
\hline 3 - Industrial Production & Positive effect & $\begin{array}{l}\text { Ramchander, Simpson and Thiewes } \\
\text { (2006) }\end{array}$ \\
\hline 4 - GDP & Positive effect & Funke and Matsuda (2002) \\
\hline 5 - Factory orders & Positive effect & Funke and Matsuda (2002) \\
\hline 6 - Retail Sales & Positive effect & $\begin{array}{l}\text { Ramchander, Simpson and Thiewes } \\
\text { (2006) }\end{array}$ \\
\hline 7 - Trade balance & Positive effect & $\begin{array}{l}\text { Kim, McKenzie and Faff (2004) } \\
\text { Ramchander, Simpson and Thiewes } \\
\text { (2006) } \\
\text { Funke and Matsuda (2002) }\end{array}$ \\
\hline 8 - Current account & Positive effect & $\begin{array}{l}\text { Ramchander, Simpson and Thiewes } \\
\text { (2006) } \\
\text { Funke and Matsuda (2002) }\end{array}$ \\
\hline 9 - Unemployment & Negative effect & $\begin{array}{l}\text { Nikkinen and Sahlstrom (2004) } \\
\text { Funke and Matsuda (2002) }\end{array}$ \\
\hline \multicolumn{3}{|l|}{ Monetary } \\
\hline 10 - Money & Negative effect & $\begin{array}{l}\text { Flannery and Protopapadakis } \\
\text { (2002) } \\
\text { Ehrman }(2004,2006) \\
\text { Thorbecke }(1997) \\
\text { He (2006) } \\
\text { Patelis (1997) }\end{array}$ \\
\hline 11 -Interest rate & Negative effect & $\begin{array}{l}\text { Flannery and Protopapadakis } \\
(2002) \\
\text { Bredin, Hyde and O'Reilly (2004) } \\
\text { Jones, Lin and Masih (2005) }\end{array}$ \\
\hline \multicolumn{3}{|l|}{$\begin{array}{l}\text { Business climate and } \\
\text { consumer confidence }\end{array}$} \\
\hline $\begin{array}{l}12 \text { - Business climate } \\
13 \text { - Consumer confidence } \\
14 \text { - ISM Index } \\
15 \text { - PMI }\end{array}$ & Positive effect & Funke and Matsuda (2002) \\
\hline
\end{tabular}

Note: For simplicity we consider the hypothetical effects of individual macroeconomic announcements. In the case of multiple announcements arriving on the market at the same time a specific announcement may dominate or set of announcements may create a combined effect (see Hanousek, Kočenda and Kutan, 2009 for details). 
Table 3: Eurozone and U.S. macroeconomic announcements entering stock markets in Prague, Budapest and Warsaw

\begin{tabular}{|c|c|c|c|c|c|c|c|c|c|}
\hline \multirow[b]{2}{*}{ Announcements } & \multicolumn{3}{|c|}{ Prague } & \multicolumn{3}{|c|}{ Budapest } & \multicolumn{3}{|c|}{ Warsaw } \\
\hline & - & $\mathbf{N}$ & + & - & $\mathbf{N}$ & + & - & $\mathbf{N}$ & + \\
\hline & \multicolumn{9}{|c|}{ Eurozone } \\
\hline Prices & & & & & & & & & \\
\hline $1-\mathrm{CPI}$ & 13 & 32 & 15 & 20 & 33 & 18 & 13 & 32 & 15 \\
\hline 2 - PPI & 17 & 19 & 5 & 17 & 19 & 5 & 17 & 17 & 4 \\
\hline \multicolumn{10}{|l|}{ Economy } \\
\hline 3 - Industrial Production & 36 & 6 & 40 & 38 & 6 & 41 & 36 & 6 & 40 \\
\hline 4 - GDP & 8 & 21 & 12 & 8 & 22 & 12 & 8 & 21 & 11 \\
\hline 5 - Factory orders & 32 & 1 & 45 & 32 & 1 & 48 & 32 & 1 & 48 \\
\hline 6 - Retail Sales & 22 & 3 & 15 & 23 & 3 & 16 & 23 & 3 & 16 \\
\hline 7 - Trade balance & 5 & 59 & 3 & 5 & 61 & 3 & 5 & 61 & 3 \\
\hline 8 - Current account & 20 & 0 & 13 & 20 & 0 & 13 & 20 & 0 & 13 \\
\hline 9 - Unemployment & 14 & 18 & 35 & 22 & 19 & 40 & 5 & 17 & 17 \\
\hline \multicolumn{10}{|l|}{ Monetary } \\
\hline 10 - Money & 27 & 2 & 9 & 28 & 2 & 9 & $\mathrm{n} / \mathrm{a}$ & $\mathrm{n} / \mathrm{a}$ & $\mathrm{n} / \mathrm{a}$ \\
\hline 11 -Interest rate & 0 & 39 & 0 & 0 & 41 & 0 & 0 & 39 & 0 \\
\hline \multicolumn{10}{|c|}{ Business climate and consumer confidence } \\
\hline 12 - Business climate & 77 & 59 & 101 & 78 & 59 & 101 & 67 & 53 & 77 \\
\hline 13 - Consumer confidence & 12 & 14 & 10 & 12 & 14 & 11 & 13 & 14 & 11 \\
\hline 14 - ISM Index & $\mathrm{n} / \mathrm{a}$ & $\mathrm{n} / \mathrm{a}$ & $\mathrm{n} / \mathrm{a}$ & $\mathrm{n} / \mathrm{a}$ & $\mathrm{n} / \mathrm{a}$ & $\mathrm{n} / \mathrm{a}$ & $\mathrm{n} / \mathrm{a}$ & $\mathrm{n} / \mathrm{a}$ & $\mathrm{n} / \mathrm{a}$ \\
\hline 15 - PMI & 13 & 21 & 6 & 13 & 19 & 6 & $\mathrm{n} / \mathrm{a}$ & $\mathrm{n} / \mathrm{a}$ & $\mathrm{n} / \mathrm{a}$ \\
\hline \multirow[t]{2}{*}{ Total } & 266 & 243 & 289 & 279 & 247 & 300 & 209 & 215 & 236 \\
\hline & \multicolumn{9}{|c|}{ U.S.A } \\
\hline \multicolumn{10}{|l|}{ Prices } \\
\hline $1-\mathrm{CPI}$ & 17 & 13 & 12 & 17 & 13 & 12 & 18 & 12 & 12 \\
\hline 2 - PPI & 40 & 10 & 36 & 38 & 10 & 36 & 40 & 10 & 34 \\
\hline \multicolumn{10}{|l|}{ Economy } \\
\hline 3 - Industrial Production & 22 & 4 & 15 & 23 & 4 & 15 & 22 & 3 & 15 \\
\hline 4 - GDP & $\mathrm{n} / \mathrm{a}$ & $\mathrm{n} / \mathrm{a}$ & $\mathrm{n} / \mathrm{a}$ & $\mathrm{n} / \mathrm{a}$ & $\mathrm{n} / \mathrm{a}$ & $\mathrm{n} / \mathrm{a}$ & $\mathrm{n} / \mathrm{a}$ & $\mathrm{n} / \mathrm{a}$ & $\mathrm{n} / \mathrm{a}$ \\
\hline 5 - Factory orders & 0 & 0 & 1 & 17 & 1 & 20 & 0 & 0 & 1 \\
\hline 6 - Retail Sales & 19 & 2 & 21 & 19 & 2 & 21 & 19 & 2 & 21 \\
\hline 7 - Trade balance & 19 & 1 & 23 & 19 & 1 & 23 & 19 & 1 & 23 \\
\hline 8 - Current account & $\mathrm{n} / \mathrm{a}$ & $\mathrm{n} / \mathrm{a}$ & $\mathrm{n} / \mathrm{a}$ & $\mathrm{n} / \mathrm{a}$ & $\mathrm{n} / \mathrm{a}$ & $\mathrm{n} / \mathrm{a}$ & $\mathrm{n} / \mathrm{a}$ & $\mathrm{n} / \mathrm{a}$ & $\mathrm{n} / \mathrm{a}$ \\
\hline 9 - Unemployment & 78 & 46 & 92 & 82 & 46 & 92 & 78 & 46 & 92 \\
\hline Monetary & $\mathrm{n} / \mathrm{a}$ & $\mathrm{n} / \mathrm{a}$ & $\mathrm{n} / \mathrm{a}$ & $\mathrm{n} / \mathrm{a}$ & $\mathrm{n} / \mathrm{a}$ & $\mathrm{n} / \mathrm{a}$ & $\mathrm{n} / \mathrm{a}$ & $\mathrm{n} / \mathrm{a}$ & $\mathrm{n} / \mathrm{a}$ \\
\hline \multicolumn{10}{|c|}{ Business climate and consumer confidence } \\
\hline 12 - Business climate & 29 & 2 & 22 & 43 & 3 & 34 & 29 & 2 & 22 \\
\hline 13 - Consumer confidence & 1 & 0 & 0 & 17 & 0 & 22 & 1 & 0 & 0 \\
\hline 14 - ISM Index & 1 & 0 & 0 & 17 & 6 & 10 & $\mathrm{n} / \mathrm{a}$ & $\mathrm{n} / \mathrm{a}$ & $\mathrm{n} / \mathrm{a}$ \\
\hline 15 - PMI & 5 & 0 & 6 & 15 & 0 & 22 & 5 & 0 & 7 \\
\hline Total & 231 & 78 & 228 & 307 & 86 & 307 & 231 & 76 & 227 \\
\hline
\end{tabular}

Note: Symbol "-“ denotes that the announcement value is below market expectations and symbol "+" denotes the opposite. Symbol "N" denotes that the announcement is in line with market expectations. Symbol " $\mathrm{n} / \mathrm{a}$ " denotes the situation when a specific type of news is not available during trading hours. Symbol "0" denotes the situation when a specific quality of news (e.g. -, N, or + ) does not materialize during trading hours. 
Table 4.A

Spillover effects and volatility: Prague stock market

\begin{tabular}{|c|c|c|c|c|c|c|c|c|c|}
\hline \multicolumn{5}{|c|}{ Mean Equation } & \multicolumn{5}{|c|}{ Volatility Equation } \\
\hline Parameter & & Coeff. & & Std.err. & Parameter & & Coeff. & & Std.err. \\
\hline \multicolumn{5}{|l|}{ Stock index return } & \multicolumn{5}{|l|}{ Volatility terms } \\
\hline $\mathrm{DAX}_{\mathrm{t}-1}$ & $\pi_{1}$ & 0,110 & $\mathrm{a}$ & $(0,003)$ & Constant & $\omega$ & $-5,373$ & $\mathrm{a}$ & $(0,003)$ \\
\hline $\mathrm{DAX}_{\mathrm{t}-2}$ & $\pi_{2}$ & 0,050 & $\mathrm{a}$ & $(0,003)$ & ARCH term & $\alpha$ & 0,342 & $\mathrm{a}$ & $(0,004)$ \\
\hline $\mathrm{DJI}_{\mathrm{t}-1}$ & $\pi_{3}$ & 0,050 & $\mathrm{a}$ & $(0,008)$ & GARCH term & $\beta$ & 0,019 & $\mathrm{a}$ & $(0,001)$ \\
\hline $\mathrm{DJI}_{\mathrm{t}-2}$ & $\pi_{4}$ & 0,019 & $\mathrm{a}$ & $(0,006)$ & \multicolumn{5}{|c|}{ Intraday volatility dummies } \\
\hline $\mathrm{BUX}_{\mathrm{t}-1}$ & $\gamma_{1}$ & 0,039 & $\mathrm{a}$ & $(0,002)$ & $\mathrm{D}_{1}$ & $\mu_{1}$ & 0,937 & $\mathrm{a}$ & $(0,049)$ \\
\hline $\mathrm{BUX}_{\mathrm{t}-2}$ & $\gamma_{2}$ & 0,027 & $\mathrm{a}$ & $(0,002)$ & $\mathrm{D}_{2}$ & $\mu_{2}$ & 0,810 & $\mathrm{a}$ & $(0,030)$ \\
\hline $\mathrm{PX}_{\mathrm{t}-1}$ & $\gamma_{3}$ & $\mathrm{n} / \mathrm{a}$ & & & $\mathrm{D}_{3}$ & $\mu_{3}$ & 0,580 & $\mathrm{a}$ & $(0,037)$ \\
\hline $\mathrm{PX}_{\mathrm{t}-2}$ & $\gamma_{4}$ & $\mathrm{n} / \mathrm{a}$ & & & $\mathrm{D}_{4}$ & $\mu_{4}$ & 0,531 & $\mathrm{a}$ & $(0,039)$ \\
\hline $\mathrm{WIG}_{\mathrm{t}-1}$ & $\gamma_{5}$ & 0,002 & & $(0,002)$ & $\mathrm{D}_{5}$ & $\mu_{5}$ & 1,099 & a & $(0,031)$ \\
\hline $\mathrm{WIG}_{\mathrm{t}-2}$ & $\gamma_{6}$ & 0,010 & $\mathrm{a}$ & $(0,002)$ & $\mathrm{D}_{\mathrm{T}-5}$ & $\mu_{6}$ & $-0,451$ & $\mathrm{a}$ & $(0,033)$ \\
\hline \multicolumn{5}{|l|}{ Year dummies } & $\mathrm{D}_{\mathrm{T}-4}$ & $\mu_{7}$ & $-0,265$ & $\mathrm{a}$ & $(0,031)$ \\
\hline \multirow{8}{*}{$\begin{array}{l}\text { year } 2004 \\
\text { year } 2005 \\
\text { year } 2006 \\
\text { year } 2007\end{array}$} & $\lambda_{1}$ & 0,003 & & $(0,001)$ & $\mathrm{D}_{\mathrm{T}-3}$ & $\mu_{8}$ & $-0,363$ & a & $(0,028)$ \\
\hline & $\lambda_{2}$ & 0,003 & & $(0,001)$ & $\mathrm{D}_{\mathrm{T}-2}$ & $\mu_{9}$ & $-0,146$ & a & $(0,029)$ \\
\hline & $\lambda_{3}$ & 0,001 & a & $(0,001)$ & $\mathrm{D}_{\mathrm{T}-1}$ & $\mu_{10}$ & $-0,115$ & $\mathrm{a}$ & $(0,031)$ \\
\hline & $\lambda_{4}$ & 0,002 & & $(0,001)$ & \multicolumn{5}{|c|}{ Day of the week dummies } \\
\hline & & & & & $\mathrm{W}_{1}$ & & 0,210 & a & $(0,005)$ \\
\hline & & & & & $\mathrm{W}_{2}$ & & 0,217 & a & $(0,004)$ \\
\hline & & & & & $\mathrm{W}_{3}$ & $\psi_{3}$ & $-0,040$ & $\mathrm{a}$ & $(0,005)$ \\
\hline & & & & & $\mathrm{W}_{4}$ & $\psi_{4}$ & 0,101 & $\mathrm{a}$ & $(0,005)$ \\
\hline Number of observations & & & & 65955 & Wald statistics & & & & 4564 \\
\hline Log likelihood & & & & 72017 & Chi-square & & & & 76 \\
\hline
\end{tabular}


Table 4.B

Effects of macroeconomic announcements: Prague stock market

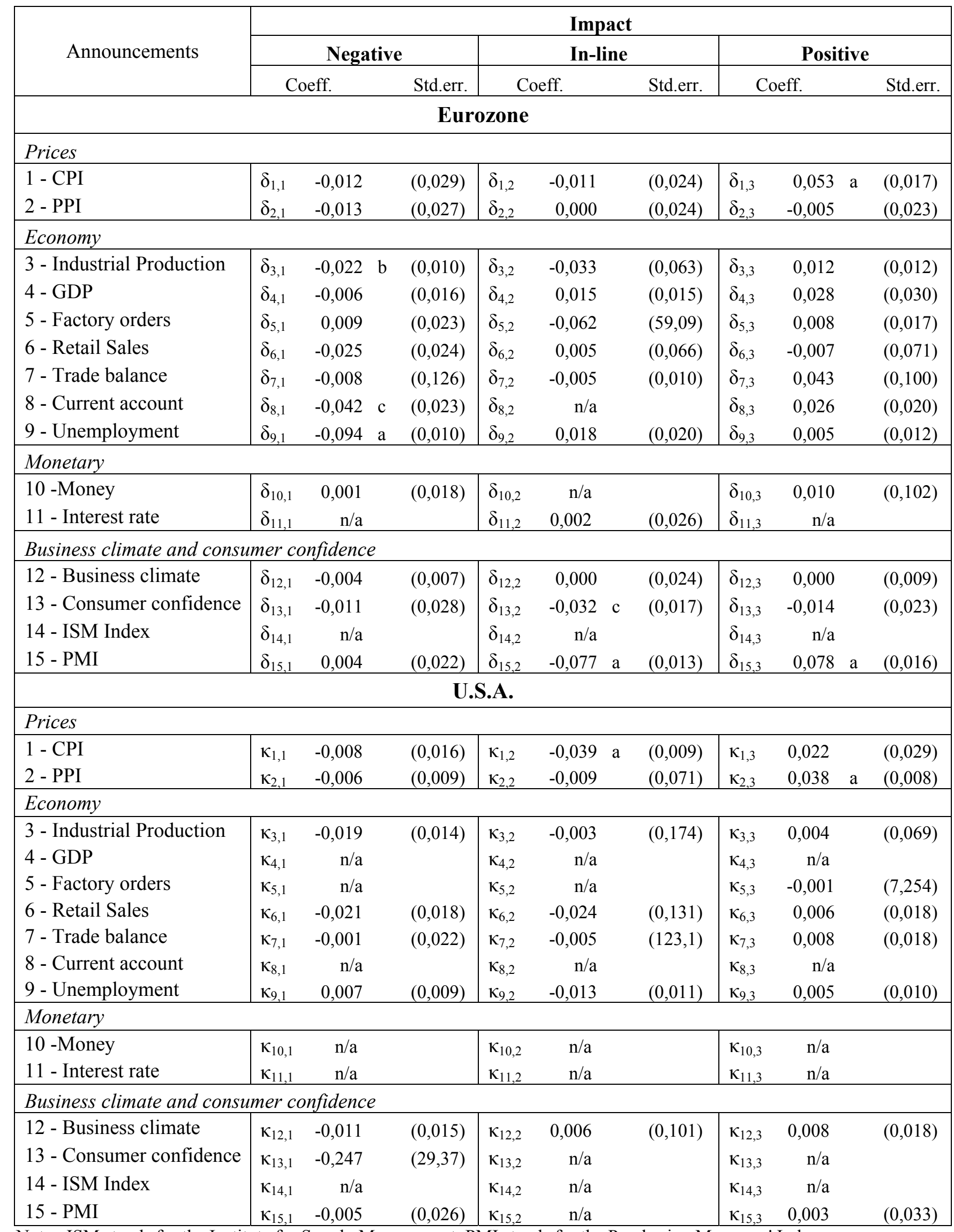

Note: ISM stands for the Institute for Supply Management; PMI stands for the Purchasing Managers' Index.

The signs $\mathrm{a}, \mathrm{b}$, and $\mathrm{c}$ denote statistical significance at the 1,5 , and $10 \%$ levels, respectively. 
Table 5.A

Spillover effects and volatility: Budapest stock market

\begin{tabular}{|c|c|c|c|c|c|c|c|c|c|}
\hline \multicolumn{5}{|c|}{ Mean Equation } & \multicolumn{5}{|c|}{ Volatility Equation } \\
\hline Parameter & & Coeff. & & Std.err. & Parameter & & Coeff. & & Std.err. \\
\hline \multicolumn{5}{|l|}{ Stock index return } & \multicolumn{5}{|l|}{ Volatility terms } \\
\hline $\mathrm{DAX}_{\mathrm{t}-1}$ & $\pi_{1}$ & 0,084 & $\mathrm{a}$ & $(0,004)$ & Constant & $\omega$ & $-5,287$ & $\mathrm{a}$ & $(0,007)$ \\
\hline $\mathrm{DAX}_{\mathrm{t}-2}$ & $\pi_{2}$ & 0,074 & $\mathrm{a}$ & $(0,004)$ & $\mathrm{ARCH}$ term & $\alpha$ & 0,291 & $\mathrm{a}$ & $(0,004)$ \\
\hline $\mathrm{DJI}_{\mathrm{t}-1}$ & $\pi_{3}$ & 0,085 & $\mathrm{a}$ & $(0,011)$ & GARCH term & $\beta$ & 0,303 & $\mathrm{a}$ & $(0,003)$ \\
\hline $\mathrm{DJI}_{\mathrm{t}-2}$ & $\pi_{4}$ & 0,002 & & $(0,012)$ & \multicolumn{5}{|c|}{ Intraday volatility dummies } \\
\hline $\mathrm{BUX}_{\mathrm{t}-1}$ & $\gamma_{1}$ & $\mathrm{n} / \mathrm{a}$ & & & $\mathrm{D}_{1}$ & $\mu_{1}$ & 2,259 & $\mathrm{a}$ & $(0,426)$ \\
\hline $\mathrm{BUX}_{\mathrm{t}-2}$ & $\gamma_{2}$ & $\mathrm{n} / \mathrm{a}$ & & & $\mathrm{D}_{2}$ & $\mu_{2}$ & 2,132 & $\mathrm{a}$ & $(0,153)$ \\
\hline $\mathrm{PX}_{\mathrm{t}-1}$ & $\gamma_{3}$ & 0,028 & $\mathrm{a}$ & $(0,003)$ & $\mathrm{D}_{3}$ & $\mu_{3}$ & 2,157 & $\mathrm{a}$ & $(0,035)$ \\
\hline $\mathrm{PX}_{\mathrm{t}-2}$ & $\gamma_{4}$ & 0,016 & a & $(0,002)$ & $\mathrm{D}_{4}$ & $\mu_{4}$ & 1,334 & $\mathrm{a}$ & $(0,046)$ \\
\hline $\mathrm{WIG}_{\mathrm{t}-1}$ & $\gamma_{5}$ & 0,006 & $\mathrm{~b}$ & $(0,003)$ & $\mathrm{D}_{5}$ & $\mu_{5}$ & 0,883 & $\mathrm{a}$ & $(0,088)$ \\
\hline $\mathrm{WIG}_{\mathrm{t}-2}$ & $\gamma_{6}$ & 0,015 & $\mathrm{a}$ & $(0,003)$ & $\mathrm{D}_{\mathrm{T}-5}$ & $\mu_{6}$ & 0,487 & $\mathrm{a}$ & $(0,054)$ \\
\hline \multicolumn{5}{|l|}{ Year dummies } & $\mathrm{D}_{\mathrm{T}-4}$ & $\mu_{7}$ & 0,488 & $\mathrm{a}$ & $(0,035)$ \\
\hline \multirow{8}{*}{$\begin{array}{l}\text { year } 2004 \\
\text { year } 2005 \\
\text { year } 2006 \\
\text { year } 2007\end{array}$} & $\lambda_{1}$ & 0,001 & $\mathrm{~b}$ & $(0,001)$ & $\mathrm{D}_{\mathrm{T}-3}$ & $\mu_{8}$ & $-0,162$ & $\mathrm{~b}$ & $(0,073)$ \\
\hline & $\lambda_{2}$ & 0,001 & a & $(0,001)$ & $\mathrm{D}_{\mathrm{T}-2}$ & $\mu_{9}$ & 0,112 & & $(0,069)$ \\
\hline & $\lambda_{3}$ & $-0,001$ & $\mathrm{~b}$ & $(0,001)$ & $\mathrm{D}_{\mathrm{T}-1}$ & $\mu_{10}$ & 0,394 & $\mathrm{a}$ & $(0,063)$ \\
\hline & $\lambda_{4}$ & $-0,003$ & $\mathrm{~b}$ & $(0,001)$ & \multicolumn{5}{|c|}{ Day of the week dummies } \\
\hline & & & & & $\mathrm{W}_{1}$ & $\psi_{1}$ & $-0,026$ & $\mathrm{a}$ & $(0,008)$ \\
\hline & & & & & $\mathrm{W}_{2}$ & $\psi_{2}$ & $-0,039$ & $\mathrm{a}$ & $(0,010)$ \\
\hline & & & & & $\mathrm{W}_{3}$ & $\psi_{3}$ & $-0,110$ & $\mathrm{a}$ & $(0,009)$ \\
\hline & & & & & $\mathrm{W}_{4}$ & $\psi_{4}$ & $-0,027$ & $\mathrm{a}$ & $(0,009)$ \\
\hline Number of observations & & & & 72180 & Wald statistics & & & & 1458 \\
\hline Log likelihood & & & & 62001 & Chi-square & & & & 82 \\
\hline
\end{tabular}


Table 5.B

Effects of macroeconomic announcements: Budapest stock market

\begin{tabular}{|c|c|c|c|c|c|c|c|c|c|c|c|}
\hline \multirow{3}{*}{ Announcements } & \multicolumn{11}{|c|}{ Impact } \\
\hline & \multicolumn{3}{|c|}{ Negative } & \multicolumn{4}{|c|}{ In-line } & \multicolumn{4}{|c|}{ Positive } \\
\hline & \multicolumn{2}{|c|}{ Coeff. } & \multirow{2}{*}{$\frac{\text { Std.err. }}{\text { Fur }}$} & \multicolumn{2}{|c|}{ Coeff. } & & Std.err. & \multicolumn{2}{|c|}{ Coeff. } & \multicolumn{2}{|r|}{ Std.err } \\
\hline \multicolumn{11}{|c|}{ Eurozone } & \\
\hline \multicolumn{12}{|l|}{ Prices } \\
\hline $1-\mathrm{CPI}$ & $\delta_{1,1}$ & $-0,016$ & $(0,029)$ & $\delta_{1,2}$ & 0,014 & & $(0,017)$ & $\delta_{1,3}$ & 0,005 & & $(0,024)$ \\
\hline 2 - PPI & $\delta_{2,1}$ & $-0,019$ & $(0,026)$ & $\delta_{2,2}$ & $-0,026$ & & $(0,033)$ & $\delta_{2,3}$ & 0,029 & & $(0,045)$ \\
\hline \multicolumn{12}{|l|}{ Economy } \\
\hline 3 - Industrial Production & $\delta_{3,1}$ & $-0,005$ & $(0,019)$ & $\delta_{3,2}$ & 0,019 & & $(0,066)$ & $\delta_{3,3}$ & 0,002 & & $(0,013)$ \\
\hline 4 - GDP & $\delta_{4,1}$ & $-0,014$ & $(0,020)$ & $\delta_{4,2}$ & 0,085 & $\mathrm{a}$ & $(0,022)$ & $\delta_{4,3}$ & 0,030 & & $(0,037)$ \\
\hline 5 - Factory orders & $\delta_{5,1}$ & $-0,014$ & $(0,030)$ & $\delta_{5,2}$ & $-0,011$ & & (35909) & $\delta_{5,3}$ & 0,009 & & $(0,017)$ \\
\hline 6 - Retail Sales & $\delta_{6,1}$ & $-0,012$ & $(0,032)$ & $\delta_{6,2}$ & $-0,115$ & & $(0,138)$ & $\delta_{6,3}$ & 0,016 & & $(0,016)$ \\
\hline 7 - Trade balance & $\delta_{7,1}$ & $-0,022$ & $(0,060)$ & $\delta_{7,2}$ & $-0,026$ & $\mathrm{~b}$ & $(0,012)$ & $\delta_{7,3}$ & 0,034 & & $(0,136)$ \\
\hline 8 - Current account & $\delta_{8,1}$ & $-0,038$ & $(0,040)$ & $\delta_{8,2}$ & $\mathrm{n} / \mathrm{a}$ & & & $\delta_{8,3}$ & 0,059 & $\mathrm{~b}$ & $(0,028)$ \\
\hline 9 - Unemployment & $\delta_{9,1}$ & $-0,025 \quad b$ & $(0,012)$ & $\delta_{9,2}$ & 0,019 & & $(0,020)$ & $\delta_{9,3}$ & 0,009 & & $(0,011)$ \\
\hline \multicolumn{12}{|l|}{ Monetary } \\
\hline 10 -Money & $\delta_{10,1}$ & $-0,023$ & $(0,023)$ & $\delta_{10,2}$ & $\mathrm{n} / \mathrm{a}$ & & & $\delta_{10,3}$ & 0,005 & & $(0,018)$ \\
\hline 11 - Interest rate & $\delta_{11,1}$ & $\mathrm{n} / \mathrm{a}$ & & $\delta_{11,2}$ & 0,012 & & $(0,019)$ & $\delta_{11,3}$ & $\mathrm{n} / \mathrm{a}$ & & \\
\hline \multicolumn{12}{|c|}{ Business climate and consumer confidence } \\
\hline 12 - Business climate & $\delta_{12,1}$ & $-0,006$ & $(0,006)$ & $\delta_{12,2}$ & $-0,016$ & & $(0,013)$ & $\delta_{12,3}$ & 0,005 & & $(0,010)$ \\
\hline 13 - Consumer confidence & $\delta_{13,1}$ & $-0,042 \quad b$ & $(0,020)$ & $\delta_{13,2}$ & $-0,008$ & & $(0,036)$ & $\delta_{13,3}$ & 0,003 & & $(0,028)$ \\
\hline 14 - ISM Index & $\delta_{14,1}$ & $\mathrm{n} / \mathrm{a}$ & & $\delta_{14,2}$ & $\mathrm{n} / \mathrm{a}$ & & & $\delta_{14,3}$ & & & \\
\hline 15 - PMI & $\delta_{15,1}$ & $-0,005$ & $(0,034)$ & $\delta_{15,2}$ & 0,084 & $\mathrm{a}$ & $(0,025)$ & $\delta_{15,3}$ & 0,069 & $\mathrm{~b}$ & $(0,038)$ \\
\hline \multicolumn{12}{|c|}{ U.S.A. } \\
\hline \multicolumn{12}{|l|}{ Prices } \\
\hline $1-\mathrm{CPI}$ & $\kappa_{1,1}$ & $-0,016$ & $(0,028)$ & $\kappa_{1,2}$ & 0,029 & $\mathrm{c}$ & $(0,015)$ & $\kappa_{1,3}$ & 0,032 & & $(0,037)$ \\
\hline 2 - PPI & $\kappa_{2,1}$ & $-0,002$ & $(0,018)$ & $\kappa_{2,2}$ & $-0,020$ & & $(0,028)$ & $\kappa_{2,3}$ & 0,002 & & $(0,014)$ \\
\hline \multicolumn{12}{|l|}{ Economy } \\
\hline 3 - Industrial Production & $\kappa_{3,1}$ & $-0,025$ & $(0,022)$ & $\kappa_{3,2}$ & 0,038 & & $(0,086)$ & $\kappa_{3,3}$ & 0,044 & & $(0,030)$ \\
\hline 4 - GDP & $\kappa_{4,1}$ & $\mathrm{n} / \mathrm{a}$ & & $\kappa_{4,2}$ & $\mathrm{n} / \mathrm{a}$ & & & $\kappa_{4,3}$ & $\mathrm{n} / \mathrm{a}$ & & \\
\hline 5 - Factory orders & $\kappa_{5,1}$ & $-0,031$ & $(0,085)$ & $\kappa_{5,2}$ & $\mathrm{n} / \mathrm{a}$ & & & $\kappa_{5,3}$ & 0,033 & & $(0,069)$ \\
\hline 6 - Retail Sales & $\kappa_{6,1}$ & $-0,001$ & $(0,026)$ & $\kappa_{6,2}$ & 0,002 & & $(2,629)$ & $\kappa_{6,3}$ & 0,016 & & $(0,018)$ \\
\hline 7 - Trade balance & $\kappa_{7,1}$ & $-0,019$ & $(0,030)$ & $\kappa_{7,2}$ & 0,027 & & $(0,499)$ & $\kappa_{7,3}$ & 0,006 & & $(0,014)$ \\
\hline 8 - Current account & $\kappa_{8,1}$ & $\mathrm{n} / \mathrm{a}$ & & $\kappa_{8,2}$ & $\mathrm{n} / \mathrm{a}$ & & & $\kappa_{8,3}$ & $\mathrm{n} / \mathrm{a}$ & & \\
\hline 9 - Unemployment & $\kappa_{9,1}$ & $-0,007$ & $(0,012)$ & $\kappa_{9,2}$ & 0,047 & $\mathrm{a}$ & $(0,010)$ & $\kappa_{9,3}$ & 0,004 & & $(0,014)$ \\
\hline \multicolumn{12}{|l|}{ Monetary } \\
\hline 10 -Money & $\kappa_{10,1}$ & $\mathrm{n} / \mathrm{a}$ & & $\kappa_{10,2}$ & $\mathrm{n} / \mathrm{a}$ & & & $\kappa_{10,3}$ & & & \\
\hline 11 - Interest rate & $\kappa_{11,1}$ & $\mathrm{n} / \mathrm{a}$ & & $\kappa_{11,2}$ & $\mathrm{n} / \mathrm{a}$ & & & $\kappa_{11,3}$ & $\mathrm{n} / \mathrm{a}$ & & \\
\hline \multicolumn{12}{|c|}{ Business climate and consumer confidence } \\
\hline 12 - Business climate & $\kappa_{12,1}$ & $-0,012$ & $(0,022)$ & $\kappa_{12,2}$ & 0,033 & & $(0,073)$ & $\kappa_{12,3}$ & 0,003 & & $(0,024)$ \\
\hline 13 - Consumer confidence & $\kappa_{13,1}$ & $-0,031$ & $(0,040)$ & $\kappa_{13,2}$ & $\mathrm{n} / \mathrm{a}$ & & & $\kappa_{13,3}$ & 0,032 & & $(0,038)$ \\
\hline 14 - ISM Index & $\kappa_{14,1}$ & $-0,077$ a & $(0,026)$ & $\kappa_{14,2}$ & 0,041 & & $(0,068)$ & $\kappa_{14,3}$ & 0,061 & & $(0,078)$ \\
\hline 15 - PMI & $\kappa_{15,1}$ & $-0,014$ & $(0,022)$ & $\kappa_{15,2}$ & $\mathrm{n} / \mathrm{a}$ & & & $\kappa_{15,3}$ & 0,031 & & $(0,071)$ \\
\hline
\end{tabular}

Note: ISM stands for the Institute for Supply Management; PMI stands for the Purchasing Managers' Index.

The signs $\mathrm{a}, \mathrm{b}$, and $\mathrm{c}$ denote statistical significance at the 1,5 , and $10 \%$ levels, respectively. 
Table 6A

Spillover effects and volatility: Warsaw stock market

\begin{tabular}{|c|c|c|c|c|c|c|c|c|}
\hline \multicolumn{4}{|c|}{ Mean Equation } & \multicolumn{5}{|c|}{ Volatility Equation } \\
\hline Parameter & & Coeff. & Std.err. & Parameter & & Coeff. & & Std.err. \\
\hline \multicolumn{4}{|l|}{ Stock index return } & \multicolumn{5}{|l|}{ Volatility terms } \\
\hline $\mathrm{DAX}_{\mathrm{t}-1}$ & $\pi_{1}$ & 0,176 a & $(0,005)$ & Constant & $\omega$ & $-5,058$ & $\mathrm{a}$ & $(0,009)$ \\
\hline $\mathrm{DAX}_{\mathrm{t}-2}$ & $\pi_{2}$ & $0,071 \quad \mathrm{a}$ & $(0,006)$ & ARCH term & $\alpha$ & 0,261 & $\mathrm{a}$ & $(0,004)$ \\
\hline $\mathrm{DJI}_{\mathrm{t}-1}$ & $\pi_{3}$ & 0,124 a & $(0,016)$ & GARCH term & $\beta$ & 0,253 & $\mathrm{a}$ & $(0,003)$ \\
\hline $\mathrm{DJI}_{\mathrm{t}-2}$ & $\pi_{4}$ & $-0,025$ & $(0,020)$ & \multicolumn{5}{|c|}{ Intraday volatility dummies } \\
\hline $\mathrm{BUX}_{\mathrm{t}-1}$ & $\gamma_{1}$ & 0,024 a & $(0,003)$ & $\mathrm{D}_{1}$ & $\mu_{1}$ & 1,016 & $\mathrm{a}$ & $(0,061)$ \\
\hline $\mathrm{BUX}_{\mathrm{t}-2}$ & $\gamma_{2}$ & 0,041 a & $(0,003)$ & $\mathrm{D}_{2}$ & $\mu_{2}$ & 0,834 & $\mathrm{a}$ & $(0,048)$ \\
\hline $\mathrm{PX}_{\mathrm{t}-1}$ & $\gamma_{3}$ & 0,017 a & $(0,004)$ & $\mathrm{D}_{3}$ & $\mu_{3}$ & 1,527 & $\mathrm{a}$ & $(0,054)$ \\
\hline $\mathrm{PX}_{\mathrm{t}-2}$ & $\gamma_{4}$ & $-0,001$ & $(0,003)$ & $\mathrm{D}_{4}$ & $\mu_{4}$ & 1,836 & $\mathrm{a}$ & $(0,027)$ \\
\hline $\mathrm{WIG}_{\mathrm{t}-1}$ & $\gamma_{5}$ & $\mathrm{n} / \mathrm{a}$ & & $\mathrm{D}_{5}$ & $\mu_{5}$ & 0,460 & $\mathrm{a}$ & $(0,067)$ \\
\hline $\mathrm{WIG}_{\mathrm{t}-2}$ & $\gamma_{6}$ & $\mathrm{n} / \mathrm{a}$ & & $\mathrm{D}_{\mathrm{T}-5}$ & $\mu_{6}$ & 0,345 & $\mathrm{a}$ & $(0,038)$ \\
\hline \multicolumn{4}{|l|}{ Year dummies } & $\mathrm{D}_{\mathrm{T}-4}$ & $\mu_{7}$ & 0,470 & $\mathrm{a}$ & $(0,042)$ \\
\hline \multirow{8}{*}{$\begin{array}{l}\text { year } 2004 \\
\text { year } 2005 \\
\text { year } 2006 \\
\text { year } 2007\end{array}$} & $\lambda_{1}$ & 0,004 & $(0,001)$ & $\mathrm{D}_{\mathrm{T}-3}$ & $\mu_{8}$ & $-0,006$ & & $(0,054)$ \\
\hline & $\lambda_{2}$ & $0,005 \mathrm{c}$ & $(0,001)$ & $\mathrm{D}_{\mathrm{T}-2}$ & $\mu_{9}$ & 0,195 & $\mathrm{a}$ & $(0,054)$ \\
\hline & $\lambda_{3}$ & $0,005 \mathrm{c}$ & $(0,001)$ & $\mathrm{D}_{\mathrm{T}-1}$ & $\mu_{10}$ & 0,398 & $\mathrm{a}$ & $(0,062)$ \\
\hline & $\lambda_{4}$ & 0,003 & $(0,002)$ & \multicolumn{5}{|c|}{ Day of the week dummies } \\
\hline & & & & $\mathrm{W}_{1}$ & $\psi_{1}$ & 0,134 & $\mathrm{a}$ & $(0,011)$ \\
\hline & & & & $\mathrm{W}_{2}$ & $\psi_{2}$ & 0,120 & $\mathrm{a}$ & $(0,012)$ \\
\hline & & & & $\mathrm{W}_{3}$ & $\psi_{3}$ & 0,055 & $\mathrm{a}$ & $(0,011)$ \\
\hline & & & & $\mathrm{W}_{4}$ & $\psi_{4}$ & 0,132 & $\mathrm{a}$ & $(0,012)$ \\
\hline Number of observations & & & 64090 & Wald statistics & & & & 2791 \\
\hline Log likelihood & & & 46511 & Chi-square & & & & 81 \\
\hline
\end{tabular}


Table 6.B: Effects of macroeconomic announcements: Warsaw stock market

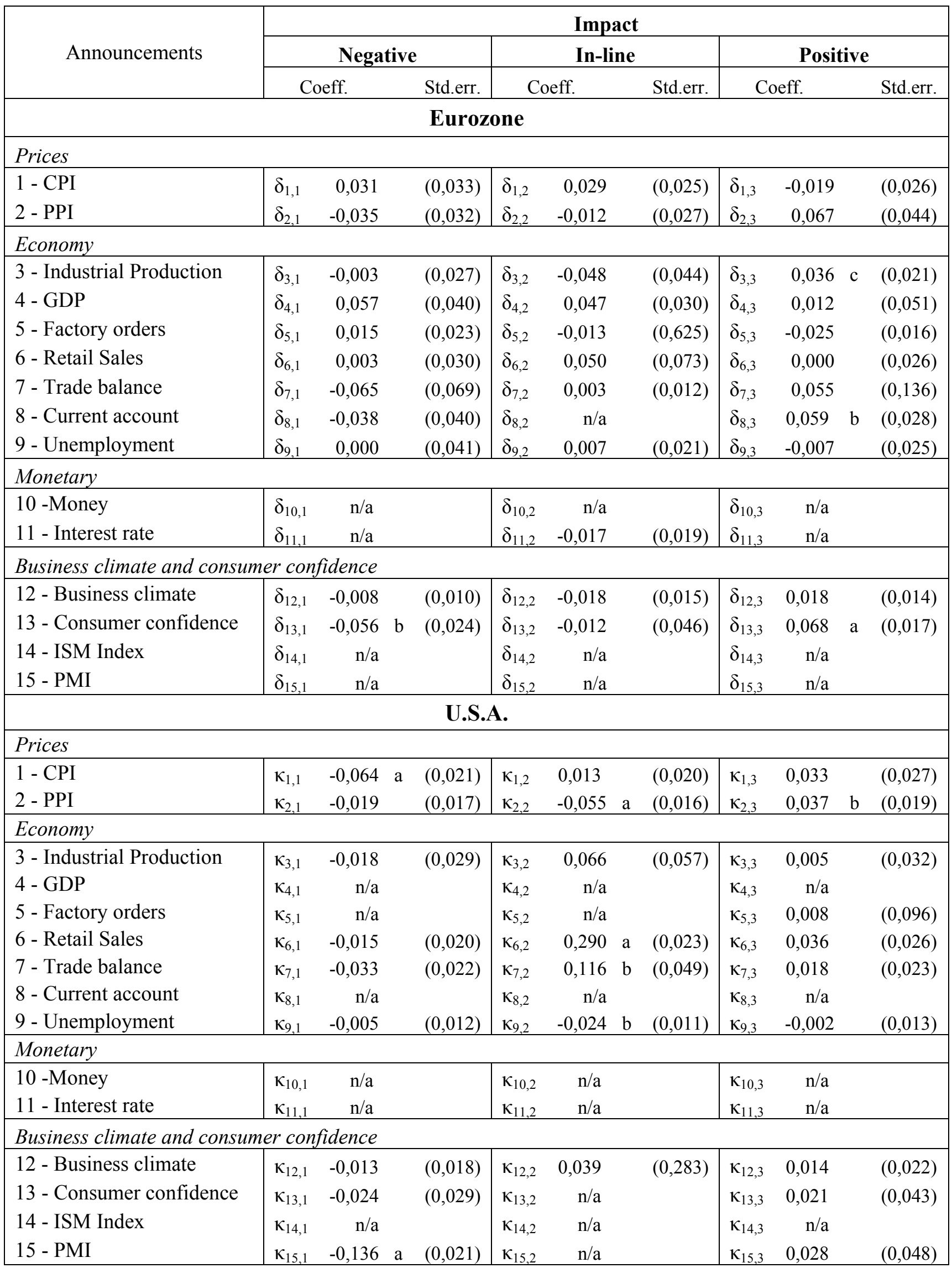

Note: ISM stands for the Institute for Supply Management; PMI stands for the Purchasing Managers' Index.

The signs $\mathrm{a}, \mathrm{b}$, and $\mathrm{c}$ denote statistical significance at the 1,5 , and $10 \%$ levels, respectively. 
Table A1.

Timing of Domestic Announcements

\begin{tabular}{|c|c|c|c|c|c|c|}
\hline Announcement type & \multicolumn{2}{|c|}{$\begin{array}{c}\text { Czech Republic } \\
{[9: 30-16.00]} \\
\end{array}$} & \multicolumn{2}{|l|}{$\begin{array}{c}\text { Hungary } \\
{[9: 00-16: 30]} \\
\end{array}$} & \multicolumn{2}{|l|}{$\begin{array}{c}\text { Poland } \\
{[10: 00-16: 00]} \\
\end{array}$} \\
\hline $\begin{array}{l}\text { Prices } \\
\text { CPI } \\
\text { PPI } \\
\end{array}$ & $\begin{array}{l}\text { 9:00 } \\
\text { 9:00 }\end{array}$ & $\begin{array}{l}* * \\
* * \\
\end{array}$ & $\begin{array}{l}\text { 9:00 } \\
\text { 9:00 }\end{array}$ & * & $\begin{array}{l}12: 00 \text { or } 16: 00 \\
14: 00 \text { or } 16: 00\end{array}$ & * \\
\hline $\begin{array}{l}\text { Economy } \\
\text { Industrial Production } \\
\text { Industrial Sales } \\
\text { Construction Output } \\
\text { GDP } \\
\text { Retail Sales } \\
\text { Wages } \\
\text { Current Account } \\
\text { Trade Balance } \\
\text { Trade Deficit } \\
\text { Unemployment } \\
\end{array}$ & $\begin{array}{c}9: 00 \\
9: 00 \\
9: 00 \\
9: 00 \\
9: 00 \\
9: 00 \\
10: 00 \\
8: 00 \text { or } 9: 00 \\
13: 45 \text { or } 15: 00 \\
08: 00 \text { or } 11: 15 \\
\end{array}$ & $\begin{array}{l}* * \\
* * \\
* * \\
* * \\
* * \\
* *\end{array}$ & $\begin{array}{c}9: 00 \\
\mathrm{~N} / \mathrm{S} \\
\mathrm{N} / \mathrm{S} \\
9: 00 \\
9: 00 \\
9: 00 \\
8: 30 \\
9: 00 \\
17: 00 \\
9: 00 \\
\end{array}$ & $\begin{array}{l}* \\
* * \\
* * \\
* \\
* \\
* \\
* * \\
* \\
* * \\
*\end{array}$ & $\begin{array}{c}\mathrm{N} / \mathrm{S} \\
14: 00 \text { or } 16: 00 \\
\mathrm{~N} / \mathrm{S} \\
10: 00 \text { or } 16: 00 \\
09: 00 \text { or } 12: 00 \\
\text { varied } \\
12: 00 \text { or } 16: 00 \\
14: 00 \text { or } 16: 00 \\
\text { varied } \\
\text { 09:00 or } 12: 00\end{array}$ & $\begin{array}{l}* * \\
* \\
* \\
* \\
* \\
* * \\
* \\
* \\
* \\
*\end{array}$ \\
\hline $\begin{array}{l}\text { Monetary } \\
\text { Interest Rate } \\
\text { Money }\end{array}$ & $\begin{array}{c}11: 15 \text { or } 13: 40 \\
\mathrm{~N} / \mathrm{S}\end{array}$ & $* *$ & $\begin{array}{c}14: 00 \text { or } 14: 20 \\
\mathrm{~N} / \mathrm{S}\end{array}$ & $* *$ & $\begin{array}{c}16: 00 \\
14: 00 \text { or } 16: 00\end{array}$ & $*$ \\
\hline
\end{tabular}

Notes: Time intervals in brackets denote trading sessions in specific markets

** denotes that announcement was released outside of trading hours.

* denotes that announcement was released at the beginning or end of the trading session.

$\mathrm{N} / \mathrm{S}$ denotes that the specific announcement is not released according to a calendar.

Several announcements do not have fixed timing for their release and varied denotes this fact. Stars attached to varied releases mean that majority of releases was made during the time defined above. 


\section{DAVIDSON INSTITUTE WORKING PAPER SERIES - Most Recent Papers}

The entire Working Paper Series may be downloaded free of charge at: www.wdi.umich.edu

CURRENT AS OF $5 / 10 / 10$

\begin{tabular}{|c|c|c|}
\hline Publication & Authors & Date \\
\hline $\begin{array}{l}\text { No. 983: Foreign News and Spillovers in Emerging European Stock } \\
\text { Markets }\end{array}$ & Evzen Kocenda and Jan Hanousek & $\begin{array}{l}\text { May } \\
2010\end{array}$ \\
\hline $\begin{array}{l}\text { No. 982: The Economic and Monetary Union's effect on (international) } \\
\text { trade: the case of Slovenia before euro adoption }\end{array}$ & $\begin{array}{l}\text { Aleksander Aristovnik and } \\
\text { Matevz Meze }\end{array}$ & $\begin{array}{l}\text { April } \\
2010\end{array}$ \\
\hline $\begin{array}{l}\text { No. 981: In Time of Troubles: Challenges and Prospects in the Middle } \\
\text { East and North Africa }\end{array}$ & Imed Drine & $\begin{array}{l}\text { April } \\
2010\end{array}$ \\
\hline No. 980: A Composite Leading Indicator of Tunisian Inflation & Mohamed Daly Sfia & $\begin{array}{l}\text { March } \\
2010\end{array}$ \\
\hline $\begin{array}{l}\text { No. 979: Financial stability, monetary autonomy and fiscal interference: } \\
\text { Bulgaria in search of its way, 1879-1913 }\end{array}$ & $\begin{array}{l}\text { Kalina Dimitrova and } \\
\text { Luca Fantacci }\end{array}$ & Feb 2010 \\
\hline $\begin{array}{l}\text { No. 978: The Supply Side of Innovation: H-1B Visa Reforms and US } \\
\text { Ethnic Invention }\end{array}$ & $\begin{array}{l}\text { William R. Kerr and } \\
\text { William F. Lincoln }\end{array}$ & Feb 2010 \\
\hline $\begin{array}{l}\text { No. 977: Data Collection Procedures Equivalence in International } \\
\text { Business Research }\end{array}$ & $\begin{array}{l}\text { Agnieszka Chidlow, } \\
\text { Anna Morgan-Thomas } \\
\text { and Pervez N. Ghauri }\end{array}$ & Feb 2010 \\
\hline $\begin{array}{l}\text { No. 976: Direct and Indirect Effects of FDI in Emerging European } \\
\text { Markets: A Survey and Meta-analysis }\end{array}$ & $\begin{array}{l}\text { Jan Hanousek, Evzen Kocenda } \\
\text { and Mathilde Maurel }\end{array}$ & $\begin{array}{l}\text { March } \\
2010\end{array}$ \\
\hline $\begin{array}{l}\text { No. 975: MODELING INSTITUTIONS, START-UPS AND PRODUCTIVITY DURING } \\
\text { TRANSITION }\end{array}$ & $\begin{array}{l}\text { Zuzana Brixiová and } \\
\text { Balázs Égert }\end{array}$ & Feb 2010 \\
\hline $\begin{array}{l}\text { No. 974: Pegging the future West African single currency in regard to } \\
\text { internal/external competitiveness: a counterfactual analysis }\end{array}$ & $\begin{array}{l}\text { Gilles Dufrénot and } \\
\text { Kimiko Sugimoto }\end{array}$ & Dec 2009 \\
\hline $\begin{array}{l}\text { No. 973: Unemployment and finance: how do financial and labour market } \\
\text { factors interact? }\end{array}$ & $\begin{array}{l}\text { Donatella Gatti, Christophe Rault } \\
\text { \& Anne-Gaël Vaubourg }\end{array}$ & $\begin{array}{c}\text { January } \\
2010\end{array}$ \\
\hline No. 972: Identifying Social Entrepreneurs Serving the Poor at the BoP & Abraham M. George & $\begin{array}{l}\text { December } \\
2009\end{array}$ \\
\hline $\begin{array}{l}\text { No. 971: Inflation dynamics and the New Keynesian Phillips curve in the } \\
\text { EU-4 }\end{array}$ & Bořek Vašíček & $\begin{array}{l}\text { October } \\
2009\end{array}$ \\
\hline $\begin{array}{l}\text { No. 970: International Financial Integration And Real Exchange Rate } \\
\text { Long-Run Dynamics In Emerging Countries: Some Panel Evidence }\end{array}$ & $\begin{array}{l}\text { Guglielmo Maria CAPORALE, } \\
\text { Thouraya HADJ AMOR } \\
\text { and Christophe RAULT }\end{array}$ & Sept 2009 \\
\hline $\begin{array}{l}\text { No. 969: Once Bitten, Twice Shy: Experiences Of A Banking Crisis } \\
\text { And Expectations Of Future Crises }\end{array}$ & Shannon Mudd \& Neven Valev & Sept 2009 \\
\hline $\begin{array}{l}\text { No. 968: Monetary policy rules and inflation process in open emerging } \\
\text { economies: evidence for } 12 \text { new EU members }\end{array}$ & Bořek Vašíček & Sept 2009 \\
\hline $\begin{array}{l}\text { No. 967: Extending Likages Between Organizational Analysis And Social } \\
\text { Structure: A Case Study Of The Celebrity-Construction Of A Chinese } \\
\text { Marketplace }\end{array}$ & Mark Jacobs & Aug 2009 \\
\hline $\begin{array}{l}\text { No. 966: Chinese state's economic cooperation related investment: An } \\
\text { investigation of its direction and some implications for outward } \\
\text { investment }\end{array}$ & $\begin{array}{l}\text { Sumon Bhaumik and } \\
\text { Catherine Yap Co }\end{array}$ & Aug 2009 \\
\hline $\begin{array}{l}\text { No. 965: Capital inflows, household debt and the boom-bust cycle in } \\
\text { Estonia }\end{array}$ & $\begin{array}{l}\text { Zuzana Brixiova, Laura Vartia } \\
\text { and Andreas Worgotter }\end{array}$ & July 2009 \\
\hline No. 964: Labour Market Felxibility in Estonia: What More Can be Done? & Zuzana Brixiova & July 2009 \\
\hline $\begin{array}{l}\text { No. 963: Market Globalization by Firms from Emerging Markets \& Small } \\
\text { Countries: An Application of the Neoclassical Trade Model }\end{array}$ & Tamir Agmon & July 2009 \\
\hline $\begin{array}{l}\text { No. 962: Central Bank Communication and Exchange Rate Volatility: A } \\
\text { GARCH Analysis }\end{array}$ & $\begin{array}{l}\text { Roman Horvath and Radovan } \\
\text { Fiser }\end{array}$ & July 2009 \\
\hline
\end{tabular}

